\title{
Snakes or Ladders? Skill Upgrading and O ccupational Mobility in the US and UK during the 1990s*
}

\author{
Richard Upward Peter Wright ${ }^{\dagger}$ \\ Leverhulme Centre for Research on Globalisation \\ and Economic Policy \\ University of Nottingham
}

October 15, 2003

Preliminary draft

\begin{abstract}
In this paper we provide an empirical link between the processes of skill upgrading and occupational mobility. An increase in the relative employment of skilled workers may be achieved either by replacing less-skilled workers with more-skilled workers, or by increasing the skill-level of workers already employed. Skill upgrading therefore has an ambiguous effect on the occupational mobility of individual workers. We use comparable individual-level panel data from the US and the UK to relate the probability of individual occupational moves to the speed of skill upgrading at the industry level. We find that in both samples the speed of skill upgrading has a positive impact on the probability of moving up the occupational ladder, while it has less impact on the probability of moving down or of leaving employment. This suggests that the process of "skill upgrading" is not necessarily detrimental to the labour market outcomes of the less-skilled, since they are themselves more likely to be promoted.
\end{abstract}

*Financial assistance from the ESRC under Project G rant R000221779 and from The Leverhulme Trust under Programme Grant F114/ BF is gratefully acknowledged

†Corresponding author: peter.wright@ nottingham.ac.uk 


\section{Introduction}

There is a large body of evidence documenting the shift in demand away from unskilled and towards skilled workers in many OECD countries. See, for example Murphy \& Welch (1993) and Berman, Bound \& Griliches (1994) for US evidence; Berman, Bound \& Machin (1998) for international evidence. It is generally accepted that this process of "skill upgrading" has been an important element in the increasing wage gap between skilled and unskilled workers, and the increasing share of employment taken by skilled workers in OECD economies.

It is also well known that there is considerable movement of individual workers between skill-levels, both within and between firms. For example, Gibbons \& Waldman (1999) summarises the literature on careers within organisations, while Farber (1999) summarises the evidence on the mobility of workers between firms.

In this paper we link these two literatures on skill upgrading and occupational mobility to consider how the process of skill upgrading impacts on the movement of individual workers between skill levels or occupations. We seek to determine the importance of industry-level shifts in demand for different types of workers on the occupational mobility of individuals. This is an important issue for two reasons.

First, because it sheds light on the mechanism by which skill upgrading is achieved. In a model such as Mortensen \& Pissarides (1998) the arrival of a new technology causes some current matches between workers and firms to become unprofitable. Firms can then choose whether to dissolve the match and exit production, or to invest in some renovation cost in order to continue production with the same worker. One obvious aspect of this renovation cost is the cost of retraining the worker to be able to use the new technology. Clearly the impact on the individual worker will be very different in these two cases. In the first, an increase in the rate of technological change (and hence in the rate of skill upgrading) will cause job loss and the interruption of individual careers. In the second case, however, skill upgrading may be positively associated with "career progression" in the sense that workers move to a higher skill level to accommodate the increased demand for higher skill workers.

Second, this analysis helps us to identify who the winners and losers are from the skill upgrading process. The choices of firms to destroy matches or upgrade their workforce will vary with the relative costs of job destruction or retraining, which will in turn vary across worker and job types.

One aspect of occupational mobility which has been considered rather less is the 
possibility that workers move to a lower skilled job. The process of skill upgrading may also have an impact on the probability that an individual moves to a lower skill level. If we view skill upgrading as occurring when old jobs are destroyed and new (higher skill) jobs are created, then an increase in the rate of skill upgrading can also cause dislocation of workers and subsequent downgrading.

To investigate these issues we use individual-level panel data from both the United States and the United Kingdom, taken from the US Panel Study of Income Dynamics (PSID) and the British Household Panel Survey (BHPS). We use individual-level panel data because we need to be able to identify the occupational movements of workers over time. The use of comparable cross-country data provides us with an opportunity to explore the robustness of our conclusions across two entirely separate labour markets, both in terms of the extent of skill upgrading and also its impacts.

For each individual in employment over the period 1991-2001 we define a current level of "skill" which is intended to be internationally consistent. We then record the extent of movement between these skill groups over annual intervals, and we examine (a) how much of the movement is likely to be caused by measurement error and (b) whether this movement has measurable impacts on wages. We then use these same skill definitions to measure the extent to which skill upgrading occurs in 18 broadly defined industries. We then estimate the partial relationship between these industry-level measures of skill upgrading and the probability of occupational mobility at the individual level, controlling for other observable factors.

\section{Some relevant literature}

As noted by Machin (2001): "A by now large academic literature has documented the changing demand for skills in many countries and has looked at the key factors underpinning the observed changes." Much of this literature stems from Berman et al. (1994), and is largely empirical, although some concept of skill-biased technological change is often cited as the most likely explanation (Card \& DiNardo 2002). An important conclusion from this literature is that the great majority of skill upgrading has occurred within rather than between industries, suggesting that shifts in demand across industries is not the primary cause. Berman et al. (1998) extend the analysis of skill upgrading to ten developed countries, and find that those industries with significant technological innovation made the largest contribution towards within-industry skill-upgrading.

There is rather less research which deals with the issue of how firms (or industries) 
adjust towards a more highly-skilled workforce. One relevant issue here is whether skill-upgrading occurs via plant entry and exit, since this is more likely to cause workers to move out of employment rather than up or down the skill ladder. Haskel \& Heden (1999, p.C70) find that the exit and entry of new plants contributes between $34 \%$ and $45 \%$ of the increase in the proportion of skilled employment in the UK. Estimates for the US from Dunne, Haltiwanger \& Troske (1997, p.125) over the period 1972-1987 find that the entry and exit of plants contribute about $36 \%$ of the increase in the proportion of non-production employment. By definition, the remainder of skill upgrading occurs within or between existing plants. These plantlevel studies cannot tell us however whether within-plant skill upgrading occurs via reallocation of existing labour or via laying off unskilled workers and taking on skilled workers.

Bartel \& Sicherman (1998) is closer in spirit to our analysis. Bartel \& Sicherman match industry-level measures of technological change to individual data from the National Longitudinal Survey of Youth (NLSY). They show that in industries with higher rates of technological change individuals are more likely to receive training. It seems likely that the receipt of training and the probability of movement to higher skill levels will be highly correlated.

The literature on the occupational mobility of individual workers has tended to concentrate on the relationship between worker characteristics (such as human capital) and the probability of promotion. Two broad strands in this literature can be identified. One, such as Sicherman \& Galor (1990) considers how fully-informed forward-looking agents choose an optimal career path which may involve movements up or across occupational "ladders" in order to maximise lifetime income. A second strand defines jobs as search or experience goods Jovanovic (1979a, 1979b), and assumes some degree of imperfect information in the matching of workers with firms. But generally the literature on the occupational mobility of workers takes the demand side as given. The issue we wish to address in this paper is how changes in the demand for different skill groups affects occupational mobility of individual workers.

\section{Data construction}

The data used are taken from waves 24-32 of the PSID and waves 1-10 of the BHPS, covering the period 1991-2001 in both the US and the UK. ${ }^{1}$ In order to

\footnotetext{
${ }^{1}$ The PSID was not conducted in 1998 and 2000, and so these years are missing in the US data. Detailed descriptions of the two datasets can be found in Hofferth et al. (1998) and Taylor et al. (2003).
} 
ensure maximum comparability between the two datasets, identical sample selection and data construction methods were used. ${ }^{2}$

Both the PSID and BHPS samples comprised heads of households and their wives taken from the core sample. The sample was restricted to heads and wives because in the PSID many relevant questions are not asked of other household members. Table 1 summarises the sample selection procedure.

Table 1: Sample selection

\begin{tabular}{|c|c|c|c|c|}
\hline & \multicolumn{2}{|c|}{$P S I D$} & \multicolumn{2}{|c|}{$B H P S$} \\
\hline & Individ. & $\begin{array}{l}\text { Person- } \\
\text { years }\end{array}$ & Individ. & $\begin{array}{c}\text { Person- } \\
\text { years }\end{array}$ \\
\hline (a) All adult core sample members & 20,990 & 129,438 & 15,344 & 124,702 \\
\hline (b) All heads and wives & 18,550 & 105,832 & 12,152 & 77,136 \\
\hline (c) Full set of valid covariates & 15,811 & 91,506 & 11,271 & 69,785 \\
\hline (d) In sample in consecutive years & 14,056 & 72,738 & 9,457 & 55,610 \\
\hline
\end{tabular}

$88 \%$ (PSID) and $80 \%$ (BHPS) of adult sample members are either a head of household or a wife of a head. Between 15\% (PSID) and 7\% (BHPS) of the original sample are lost because information on one of the covariates is missing. In order to compute transitions between years we require individuals to appear in the data in consecutive waves. All analysis that follows is therefore based on sample (d), which comprises between $76 \%$ (PSID) and $78 \%$ (BHPS) of the total sample.

\section{Definitions of skill groups}

The definition of a "skill" will always be somewhat arbitrary. Practical limitations have led many authors to distinguish only between "production" and "nonproduction" workers, or possibly between "skilled" and "unskilled". The empirical literature on occupational mobility uses a number of other classifications to

\footnotetext{
${ }^{2}$ All data construction and estimation was conducted using Stata. All code is available from the authors on request.
} 
determine whether a worker moves "up" or "down" an occupational ladder, including within-firm grading (e.g. Wise 1975), esteem indicators (e.g. Mayhew \& Roswell 1981), average earnings (e.g. Nickell 1982) or some regression-weighted combination of indicators (e.g. Sicherman \& Galor 1990).

We take the view that an occupation is an important indicator of a worker's skill level. The 1988 International Standard Classification of Occupations (ISCO-88) (International Labour Office 1990) was developed partly to provide consistent information on occupations across countries. ISCO-88 defines a skill as "the degree of complexity of constituent tasks" or alternatively "the field of knowledge required for competent performance of the constituent tasks". Similarly, Elias, McKnight \& Kingshott (1999) argue that "skill levels are linked to the length of time deemed necessary for a person to become fully competent in the performance of tasks associated with a job", and this ordering is therefore based on the kinds of occupations which can be competently performed by an individual with a certain level of education (both in school and in work).

Recognising that only a few skill level categories can usefully be identified for crossnational comparison, ISCO-88 provides four skill levels which are based on (a) the level of general education required to perform a job and (b) the job-related formal training required to perform a job.

Both the PSID and the BHPS record a three-digit occupational code for each employee. The BHPS provides the ISCO-88 occupation codes directly, while for the PSID a concordance was developed by the authors. ${ }^{3}$ From this ISCO- 88 code each employee was categorised into one of four skill levels, defined in Table 2.

How comparable are the occupations in each of these four skill groups across countries? Table 3 shows that the proportion of employees in each of the four skill groups is similar across the two samples, although there are rather more workers in the PSID in skill group 3, and rather more workers in the BHPS in skill group 4.

Although the shares of the four skill groups are similar across the two countries, this does not confirm whether those occupations in each skill group are similar. A simple check of the consistency of these definitions is provided in Appendix A, where we list in order of frequency the occupations in each skill group in both countries.

Finally, we should note that our primary objective in this paper does not rely heavily on a consistent definition of "skill" across the two countries; it merely relies on a consistent ranking within countries. It will however add considerable robustness to

\footnotetext{
${ }^{3}$ Available on request.
} 
Table 2: Definition of skill groups: ISCO-88 Skill-levels

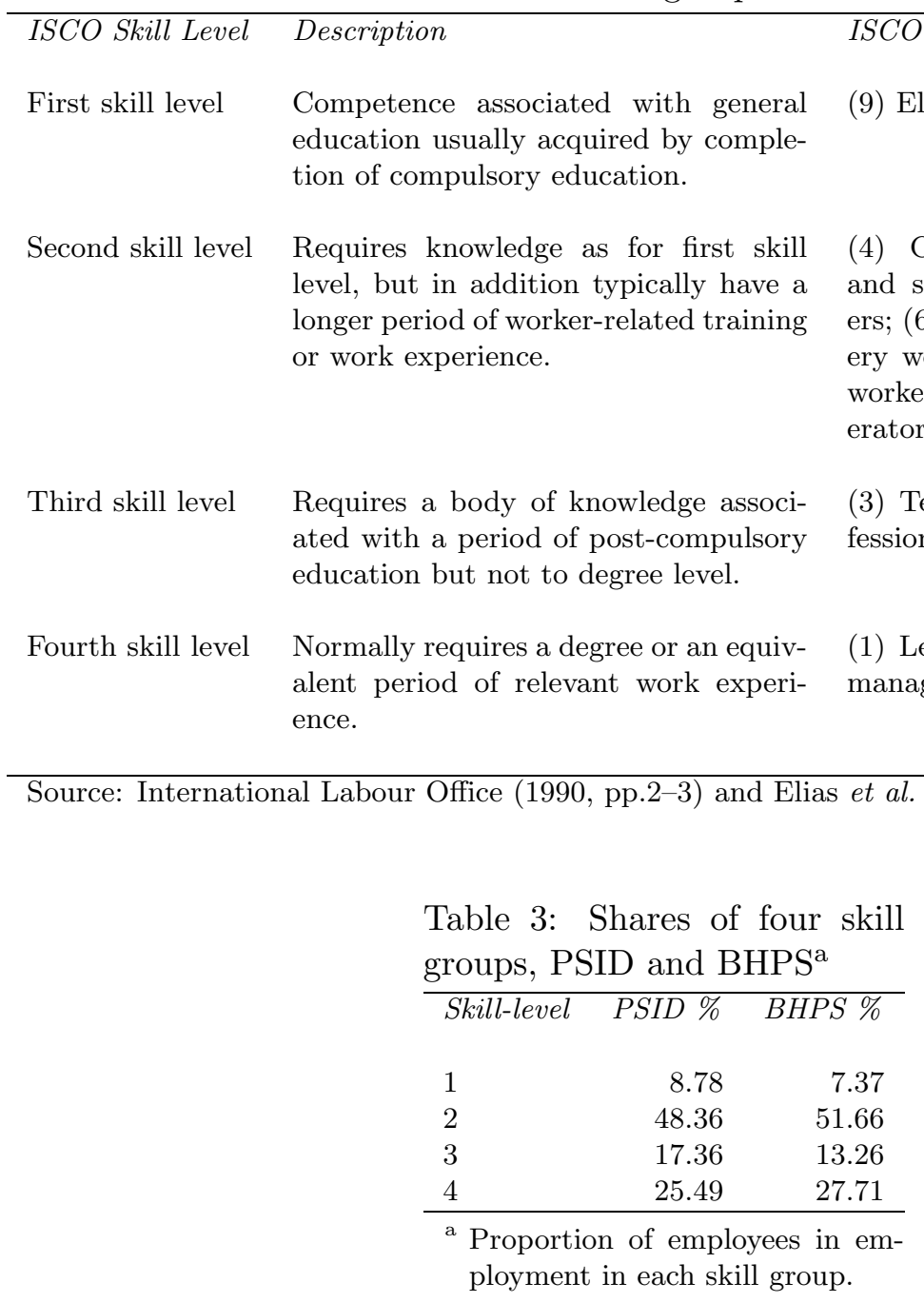

our conclusions if we find similar patterns across countries, and therefore we have taken some care to make definitions as consistent as possible.

\section{Movements up and down the skill ladder}

In both surveys individuals are asked to describe their occupation every time they are interviewed. ${ }^{4}$ Table 4 describes the patterns of movement between all four skill groups, and non-employment, over the entire period for the two samples. Comparing

\footnotetext{
${ }^{4}$ The precise wording is similar in each survey. The PSID question is "What is your main occupation? What sort of work do you do?" The BHPS asks "What was your (main) job last week? Please tell me the exact job title and describe fully the sort of work you do."
} 
the leading diagonal of these transition matrices gives an estimate of the probability of not moving skill group between successive years. In three of the four skill groups this estimate is higher for the BHPS than for the PSID, confirming that the UK experiences somewhat less mobility between skill groups. This difference is largest for the bottom skill group. Transition rates out of this skill group are some $20 \%$ higher in total in the PSID, although some of this difference is due to a higher rate of transition out of employment.

Table 4: Transitions between skill groups

\begin{tabular}{llrrrrr}
\hline (a) PSID & \multicolumn{8}{c}{ Skill group at $t$} \\
& & \multicolumn{7}{c}{} \\
& & 0 & 1 & 2 & 3 & 4 \\
& $0^{\mathrm{a}}$ & 0.871 & 0.016 & 0.069 & 0.021 & 0.023 \\
Skill & 1 & 0.164 & 0.529 & 0.258 & 0.025 & 0.025 \\
group & 2 & 0.117 & 0.044 & 0.730 & 0.048 & 0.061 \\
at $t-1$ & 3 & 0.106 & 0.010 & 0.117 & 0.656 & 0.111 \\
& 4 & 0.085 & 0.007 & 0.091 & 0.068 & 0.749
\end{tabular}

(b) $B H P S$

\begin{tabular}{|c|c|c|c|c|c|c|}
\hline & \multicolumn{6}{|c|}{ Skill group at $t$} \\
\hline & & 0 & 1 & 2 & 3 & 4 \\
\hline & $0^{\mathrm{a}}$ & 0.937 & 0.009 & 0.036 & 0.006 & 0.011 \\
\hline Skill & 1 & 0.144 & 0.622 & 0.208 & 0.012 & 0.013 \\
\hline group & 2 & 0.096 & 0.026 & 0.787 & 0.039 & 0.053 \\
\hline at $t-1$ & 3 & 0.073 & 0.007 & 0.127 & 0.655 & 0.138 \\
\hline & 4 & 0.069 & 0.003 & 0.081 & 0.056 & 0.791 \\
\hline
\end{tabular}

The first column of each matrix gives an estimate of the transition rate out of employment, into all non-employment categories grouped together. The first row gives an estimate of the transition rate into employment. As we would expect, transition rates both into and out of employment are everywhere higher for the PSID. In both samples the transition rate out of employment is declining in skill level. But transition rates into employment are highest for the second skill group rather than the first.

Perhaps the most striking fact to emerge from Table 4 is the high rates of movement both up and down skill levels. Over $25 \%$ of employees in the PSID in skill group 1 report being in skill group 2 a year later. The figure for the BHPS is just over $20 \%$. Of those in skill group 2, more than 10\% (PSID) or 9\% (BHPS) are in a higher skill group a year later. Note that in both samples those being promoted from skill group 2 are actually more likely to move to skill group 4 than skill group 3 . 
Demotion rates are also significant in size. For example, of those in skill group 3, $13 \%$ (both samples) are in a lower skill group a year later. Of those in skill group 4, $14 \%-16 \%$ move down to a lower group.

These transition matrices are sufficiently similar across countries to suggest that we are measuring a similar phenomenon. We have confirmed that employees in the US are in general more mobile both between skill groups and into and out of employment. Furthermore, despite the aggregate nature of these skill groups there appears to be substantial movement of workers between them.

\section{Measurement error}

Clearly, there is a chance of measurement error occurring either during data collection or coding. In particular, since we are trying to measure the movement of workers between occupations, changes in the way the same occupation is described by a respondent may induce changes in occupation codes without actual changes in occupation. To some extent the problem is alleviated by our use of four aggregated skill groups rather than more finely coded occupations. There are substantial differences in the types of occupation in each skill group (see Appendix A), and so it seems less likely that individuals will be misclassified.

To examine the likely extent of measurement error, in Table 5 we report the probability that a worker returns to the same skill group held 2 years earlier. Measurement error at $t$ will induce this kind of move.

Table 5: Returns to same skill level after 1 year

\begin{tabular}{lrrccc}
\hline & $(1)$ & $(2)$ & $(3)$ & $(4)$ & $(5)$ \\
Skill & $\operatorname{Pr}($ Up $)$ & $\operatorname{Pr}($ Down $)$ & $\operatorname{Pr}($ Return|up) & $\operatorname{Pr}($ Return $\mid$ down) \\
group & & & Same firm & New firm & Same firm New firm
\end{tabular}

(a) PSID

$\begin{array}{lcccccc}1 & 0.368 & - & 0.205 & 0.109 & - & - \\ 2 & 0.123 & 0.050 & 0.306 & 0.201 & 0.384 & 0.290 \\ 3 & 0.124 & 0.142 & 0.272 & 0.122 & 0.258 & 0.112 \\ 4 & - & 0.181 & - & - & 0.298 & 0.169 \\ \text { All groups } & 0.111 & 0.097 & 0.273 & 0.159 & 0.308 & 0.189\end{array}$

(b) BHPS

\begin{tabular}{lcccccr}
1 & 0.273 & - & 0.204 & 0.090 & - & - \\
2 & 0.101 & 0.028 & 0.284 & 0.222 & 0.413 & 0.235 \\
3 & 0.149 & 0.144 & 0.254 & 0.174 & 0.263 & 0.138 \\
4 & - & 0.150 & - & - & 0.338 & 0.186 \\
All groups & 0.091 & 0.076 & 0.262 & 0.173 & 0.331 & 0.188 \\
\hline
\end{tabular}


The first two columns report the estimated probability of moving to a higher and lower occupation. ${ }^{5}$ The remaining columns report the estimated probability of returning to the same skill group, conditional on having moved up and down. It seems likely that changes in occupation are more likely to be genuine when individuals also report a change of employer. In both the PSID and the BHPS one can calculate whether an individual changed employer over the preceding 12 months. ${ }^{6}$ We therefore split the probability of return between those who changed employer and those who remained at the same firm.

Of those workers who reported a movement to a higher skill group but no change of employer (column 3), 27\% return to the same skill group a year later in the PSID, and $26 \%$ in the BHPS. This rate is about three times greater than the rate of demotion in the sample as a whole (column 2), strongly suggesting the existence of measurement error. The rate of downgrading of those who reported promotion in the previous period and changed firm is $16 \%$ in the PSID and $17 \%$ in the BHPS, some 1.6-2.3 times greater than the rate of promotion in the sample as a whole.

A similar pattern emerges for workers who report returning to the same skill group following a demotion in the previous year (columns 5 and 6). Of those who do not change employer, 31\% (PSID) and 33\% (BHPS) return to the same skill group. Again, this rate is about three times greater than the rate of promotion for the sample as a whole.

\section{Wage effects of occupational mobility}

Table 5 probably provides an upper bound on the extent of measurement error, since many of the transitions will in fact be genuine. Nevertheless, some noise is likely to be present in our data. It is therefore important to determine whether reported occupational mobility has an effect on other quantifiable labour market outcomes, such as wages. In Table 6 we report average hourly wages split by the movement of workers over the preceding 12 months. These results provide strong evidence that we are picking up a genuine phenomenon in Table 4, despite some measurement error. Workers who move down between skill groups suffer wage losses of $19 \%-25 \%$ in the PSID and $19 \%-24 \%$ in the BHPS, compared to workers who remain in the same skill group. The size of the loss is very similar across countries and in both cases

\footnotetext{
${ }^{5}$ These estimates are not the same as those reported in Table 4 because here we exclude completely movements into and out of employment. The denominator is therefore smaller and estimates of movement probabilities higher.

${ }^{6}$ In the PSID individuals are asked for the date when they started working for their present employer. In the BHPS individuals are asked whether they held any jobs in the previous 12 months with a different employer.
} 
increases with skill level. Workers who move up between skill groups gain 9\%-21\% in the PSID and 11\%-24\% in the BHPS compared to workers who remain in the same skill group.

Table 6: Raw wage effects of occupational movement

\begin{tabular}{|c|c|c|c|c|c|}
\hline \multicolumn{6}{|l|}{ (a) PSID } \\
\hline \multirow[b]{2}{*}{ Skill-group } & \multicolumn{3}{|c|}{ Wage level $\$$} & \multicolumn{2}{|c|}{ Wage change \% } \\
\hline & Down & Same & $U p$ & $\begin{array}{r}\text { Downgrading } \\
\text { Penalty }\end{array}$ & $\begin{array}{r}\text { Upgrading } \\
\text { Bonus }\end{array}$ \\
\hline 1 & - & 8.73 & 9.91 & - & $13.52 \%$ \\
\hline 2 & 9.34 & 11.49 & 12.57 & $-18.71 \%$ & $9.40 \%$ \\
\hline 3 & 11.20 & 14.48 & 17.46 & $-22.65 \%$ & $20.58 \%$ \\
\hline 4 & 15.20 & 20.17 & - & $-24.64 \%$ & - \\
\hline \multicolumn{6}{|l|}{ (b) $B H P S$} \\
\hline & \multicolumn{3}{|c|}{ Wage level $£$} & \multicolumn{2}{|c|}{ Wage change \% } \\
\hline Skill-group & Down & Same & $U p$ & $\begin{array}{r}\text { Downgrading } \\
\text { Penalty }\end{array}$ & $\begin{array}{r}\text { Upgrading } \\
\text { Bonus }\end{array}$ \\
\hline 1 & - & 4.84 & 5.37 & - & $10.95 \%$ \\
\hline 2 & 5.10 & 6.26 & 7.74 & $-18.53 \%$ & $23.64 \%$ \\
\hline 3 & 7.20 & 8.91 & 10.45 & $-19.19 \%$ & $17.28 \%$ \\
\hline 4 & 8.95 & 11.84 & - & $-24.41 \%$ & - \\
\hline
\end{tabular}

These results establish that, despite the possibility of measurement error, the process of occupational mobility has large measurable effects on wages. Second, they establish that this process is very similar in both countries.

To investigate the wage effect further, we estimate the impact of mobility on wages conditional on a basic set of individual characteristics. The model estimated is:

$$
\ln w_{i t}=\beta_{0}+\boldsymbol{\beta}_{1} U_{i t} \mathbf{s}_{i, t-1}+\boldsymbol{\beta}_{2} D_{i t} \mathbf{s}_{i, t-1}+\boldsymbol{\beta}_{3} \mathbf{s}_{i, t-1}+\boldsymbol{\beta}_{4} \mathbf{x}_{i t}+\varepsilon_{i t} .
$$

The dummy variables $U_{i t}$ and $D_{i t}$ are defined as $U_{i t}=1\left(s_{i t}>s_{i, t-1}\right)$ (promotion) and $D_{i t}=1\left(s_{i t}<s_{i, t-1}\right)$ (demotion). We estimate the relationship separately for each skill group at $t-1 s_{i, t-1}$ by interacting these dummies with a vector of dummies $\mathbf{s}_{i, t-1}$ which indicate each skill group i.e. $\mathbf{s}_{i, t-1}=\left[S_{i, t-1}^{1} S_{i, t-1}^{2} S_{i, t-1}^{3} S_{i, t-1}^{4}\right]$ where e.g. $S_{i, t-1}^{1}=1\left(s_{i, t-1}=1\right)$. We also include the set of dummies $\mathbf{s}_{i, t-1}$ directly in the regression, as well as $\mathbf{x}_{i t}$ a basic set of individual characteristics measuring age, gender and education. The vectors of coefficients $\boldsymbol{\beta}_{1}$ and $\boldsymbol{\beta}_{2}$ can be interpreted as the approximate percentage change in wages for an individual in each skill group who is promoted or demoted between $t-1$ and $t$.

In Table 7 we report estimates of Equation (1). We estimate (1) separately for within- and between-firm moves to see whether the greater possibility of measure- 
ment error observed for within-firm moves affects the significance of the wage effect of occupational movements.

The results are robust to the inclusion of worker characteristics, and are all highly significant with the exception of between-firm upgrades in the BHPS. Workers who change to a lower skill group and change employer suffer particularly large wage losses of between 19\%-40\% in the PSID and 15\%-36\% in the BHPS. As in the raw data, the extent of wage loss is increasing with skill group. In contrast, workers who move up skill groups and change employer do not necessarily gain more than those who are promoted within firms.

Table 7: Conditional wage effects of occupational

\begin{tabular}{|c|c|c|c|c|}
\hline \multicolumn{5}{|l|}{ Within-firm moves } \\
\hline & \multicolumn{2}{|c|}{ (a) PSID } & \multicolumn{2}{|c|}{ (b) $B H P S$} \\
\hline & Coeff. ${ }^{\mathrm{a}}$ & S.E. & Coeff. & S.E. \\
\hline Down (skill group 2) & -0.160 & $(0.017)$ & -0.145 & $(0.022)$ \\
\hline Down (skill group 3) & -0.133 & $(0.020)$ & -0.133 & $(0.022)$ \\
\hline Down (skill group 4) & -0.120 & $(0.015)$ & -0.205 & $(0.018)$ \\
\hline Up (skill group 1) & 0.120 & $(0.019)$ & 0.085 & $(0.024)$ \\
\hline Up (skill group 2) & 0.100 & $(0.012)$ & 0.182 & $(0.013)$ \\
\hline Up (skill group 3) & 0.101 & $(0.021)$ & 0.114 & $(0.024)$ \\
\hline \multicolumn{5}{|l|}{ Between-firm moves } \\
\hline & \multicolumn{2}{|c|}{ (a) PSID } & \multicolumn{2}{|c|}{ (b) $B H P S$} \\
\hline & Coeff. & S.E. & Coeff. & S.E. \\
\hline Down (skill group 2) & -0.188 & $(0.024)$ & -0.146 & $(0.038)$ \\
\hline Down (skill group 3) & -0.344 & $(0.034)$ & -0.314 & $(0.048)$ \\
\hline Down (skill group 4) & -0.406 & $(0.032)$ & -0.360 & $(0.039)$ \\
\hline Up (skill group 1) & 0.099 & $(0.033)$ & 0.070 & $(0.053)$ \\
\hline Up (skill group 2) & 0.136 & $(0.021)$ & 0.178 & $(0.031)$ \\
\hline Up (skill group 3) & 0.082 & $(0.042)$ & 0.065 & $(0.053)$ \\
\hline
\end{tabular}

Table 7 therefore provides more evidence that the movements we observe between skill groups have real consequences on wages, even though they may be contaminated by measurement error. Indeed, we might expect that measurement error would attenuate these effects, suggesting the movement between skill groups has even larger impacts on wages than those reported here. It also appears that demotion between firms has particularly large negative effects on wages, while promotion within and between firms has approximately the same positive impact on wages. 


\section{$5 \quad$ Skill intensity and skill upgrading}

We have now established the extent of occupational mobility in each country and also the fact that mobility has large effects on wages. In this section we aggregate up measures of skill across industries to compare patterns of skill intensity and skill upgrading across the US and UK. We do this in order to construct the key explanatory variable of the model, which is the speed with which industries have increased their skill intensity over the sample period.

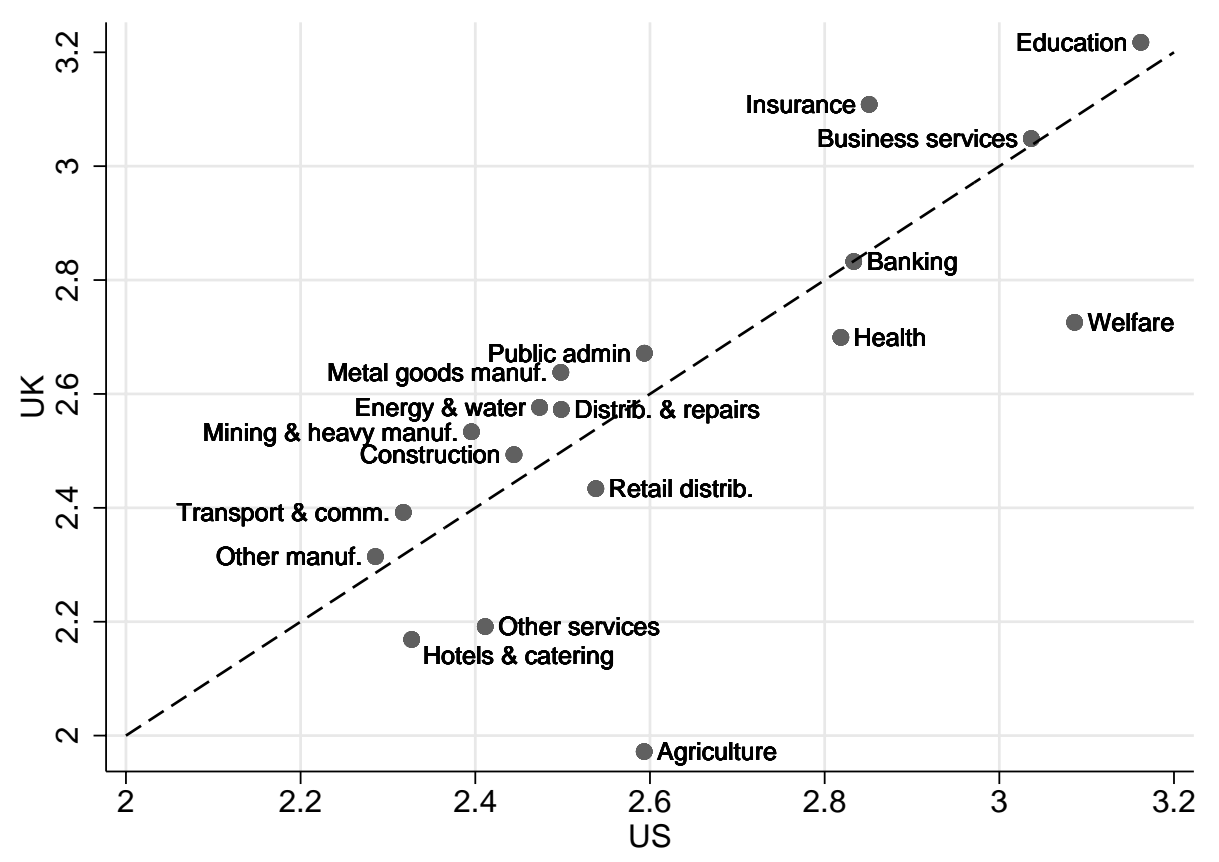

Figure 1: Average skill intensity by industry, PSID and BHPS

An initial crude measure of "skill intensity" is to take the arithmetic mean of the skill index $s_{i t}=1,2,3,4$ for each industry over the sample period. In Figure 1 we plot this measure for each country for 18 industries. $^{7}$ Using this simple measure it is clear that industries in the UK and US have generally similar skill intensity, with the obvious outlier of agriculture.

In Figure 2 we plot the proportion of employment in each skill group $s_{i t}$ separately by industry. This reveals more clearly discrepancies between occupational definitions in the two countries, although the correlation is still high.

As noted, the key explanatory variable in our model is the speed with which in-

\footnotetext{
${ }^{7}$ Our choice of industry is determined by the available sample size of the micro-data. Industries were chosen so that at least 100 sample respondents worked in that industry in each year.
} 

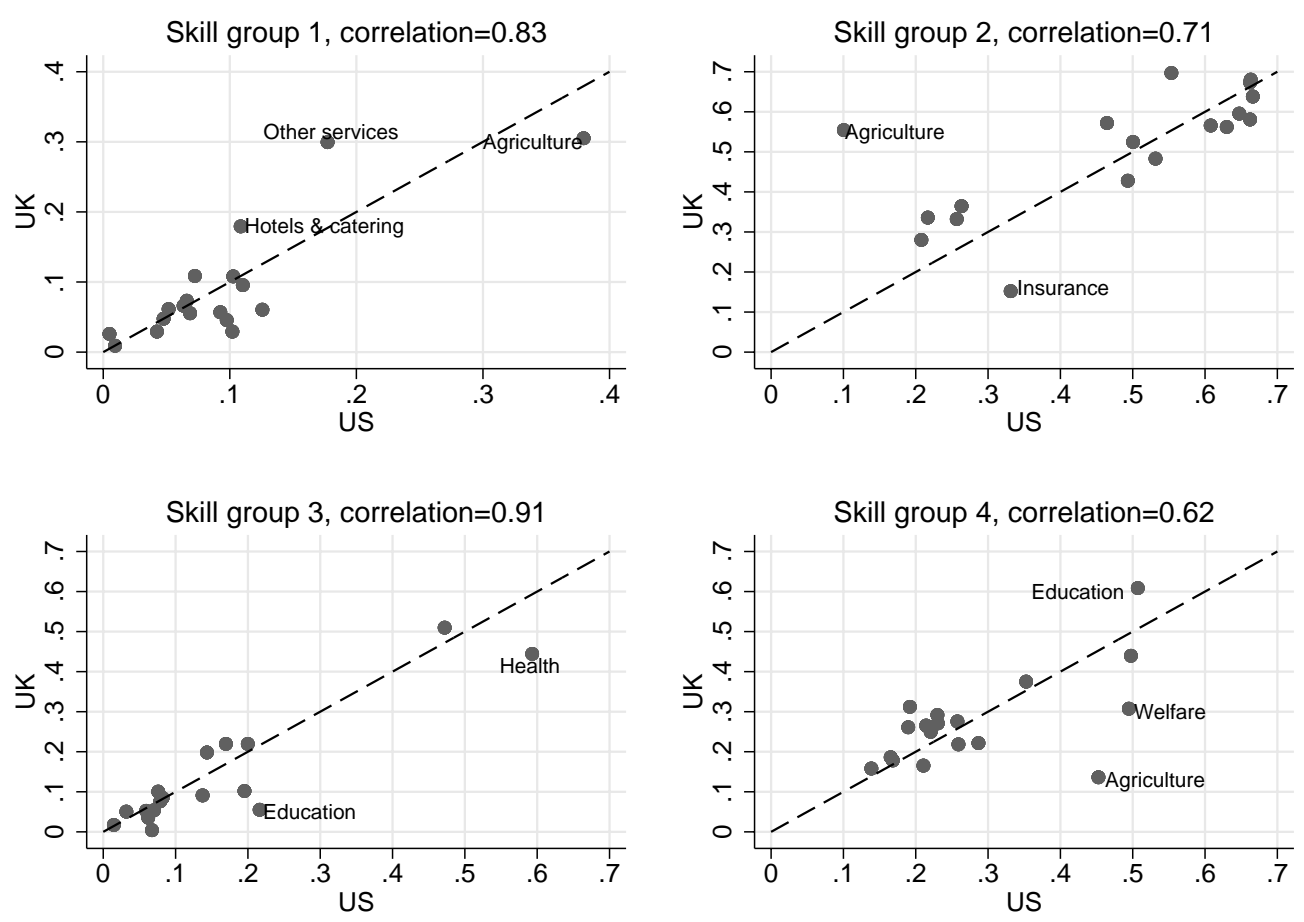

Figure 2: Proportion of employment by skill group, PSID and BHPS

dustries have upgraded the skill intensity of their workforce. In Figure 3 we plot the annual average change in the proportion of employment in each skill group by industry. It is clear that although the levels of skill intensity are quite similar across countries, there is more variation in the speed with which industries have changed their skill intensity. ${ }^{8}$ One can see that the majority of industries in both countries have reduced the proportion of workers in skill group 1 (top left hand quadrant), and increased the proportion in skill group 4 (bottom right). But changes in the proportion of workers in the middle two skill groups are more varied.

However, the fact that industries have increased their skill intensities at different rates between the US and UK provides an additional variability in the data with which to check the robustness of our results. If the speed of skill upgrading has a significant effect on the probability of promotion or demotion, and that effect is coming from different industries in each country we can be confident that it is not the result of some industry specific effect.

\footnotetext{
${ }^{8}$ The correlation coefficient between the two countries is of the same order of magnitude as that found by Berman et al. (1998, Table IV), who compared the shares of nonproduction workers by industry.
} 

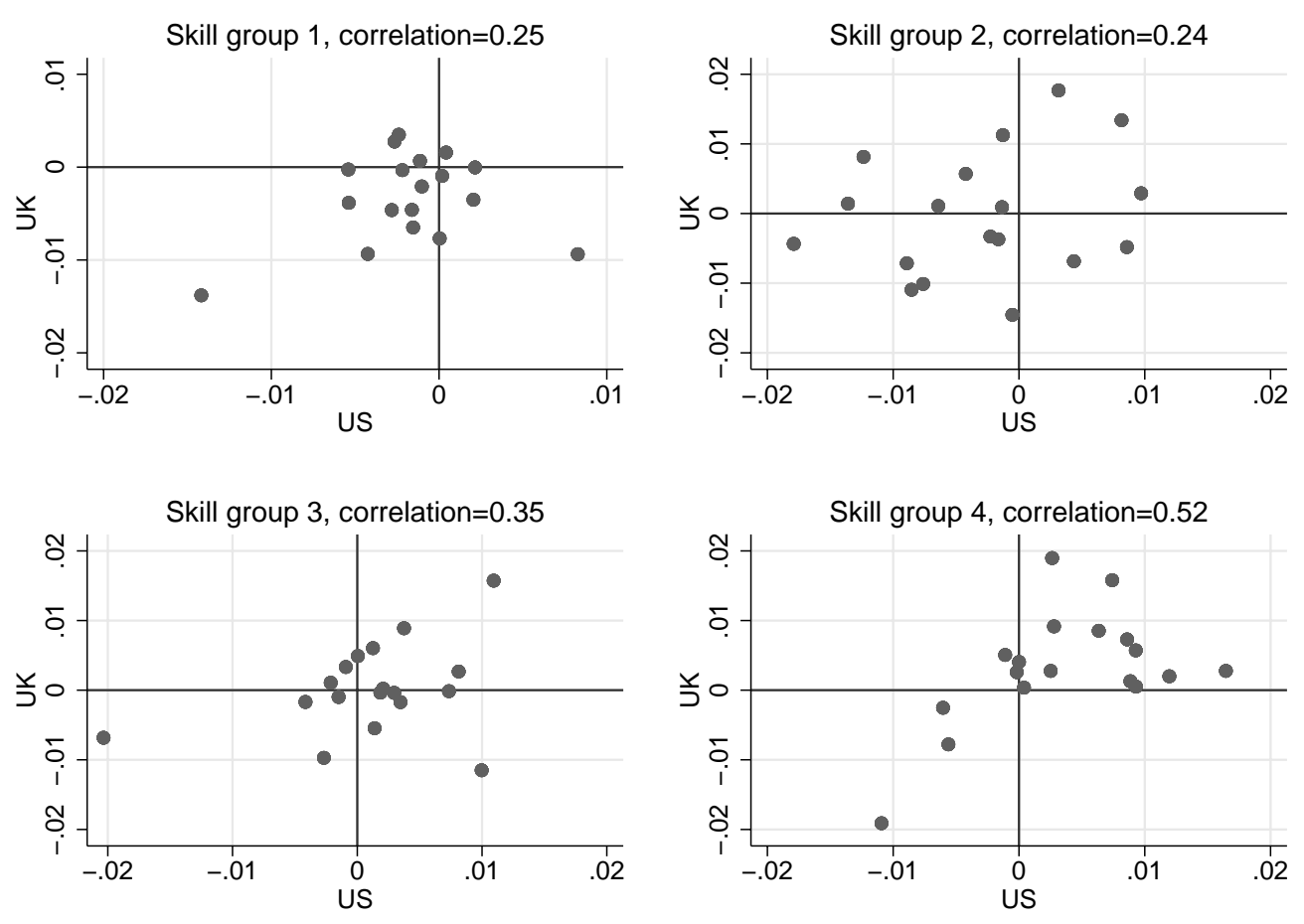

Figure 3: Change in proportion of employment by skill group, PSID and BHPS

\section{The relationship between skill upgrading and occupa- tional mobility}

In this section we investigate whether the speed of skill upgrading has had any influence on patterns of occupational mobility. We have two specific objectives:

1. Does the speed of skill upgrading in an industry lead to greater upward mobility of workers, or does it lead to a greater rate of job loss and downward mobility?

2. Is the speed of skill upgrading in an industry a quantitatively important component of occupational mobility, or is it relatively unimportant compared to the influence of individual worker characteristics?

The three basic models we estimate are binary Probit models which relate the probability of promotion, demotion and exit to a set of industry-level measures of skill upgrading. ${ }^{9}$

\footnotetext{
${ }^{9}$ It might be thought appropriate to model the movement between skill groups as a single multinomial response. In fact, estimating models (2) to (4) as a 4-way Multinomial Logit makes little difference to our results. The results of this exercise are reported in Appendix B.
} 


$$
\begin{gathered}
\operatorname{Pr}\left(s_{t}>s_{t-1} \mid s_{t-1}\right)=\Phi\left(\sum_{s=1}^{4} \boldsymbol{\beta}_{\mathrm{up}}^{s} \Delta P_{j t}^{s}+\boldsymbol{\gamma}_{\mathrm{up}}^{s} \mathbf{x}_{i, t-1}+\boldsymbol{\delta}_{\mathrm{up}}^{s} \mathbf{I}_{j}\right) \\
\operatorname{Pr}\left(s_{t}<s_{t-1} \mid s_{t-1}\right)=\Phi\left(\sum_{s=1}^{4} \boldsymbol{\beta}_{\mathrm{down}}^{s} \Delta P_{j t}^{s}+\boldsymbol{\gamma}_{\mathrm{down}}^{s} \mathbf{x}_{i, t-1}+\boldsymbol{\delta}_{\mathrm{down}}^{s} \mathbf{I}_{j}\right) \\
\operatorname{Pr}\left(s_{t}=0 \mid s_{t-1} \neq 0, s_{t-1}\right)=\Phi\left(\sum_{s=1}^{4} \boldsymbol{\beta}_{\mathrm{out}}^{s} \Delta P_{j t}^{s}+\boldsymbol{\gamma}_{\mathrm{out}}^{s} \mathbf{x}_{i, t-1}+\boldsymbol{\delta}_{\mathrm{out}}^{s} \mathbf{I}_{j}\right)
\end{gathered}
$$

Equation (2) is the probability of moving up the skill ladder. It is estimated separately for each skill group $s$ at $t-1$, and is a function of the change in the proportion of employment in each skill group $s$, industry $j$ between $t-1$ and $t$ :

$$
P_{j t}^{s}=\frac{N_{j t}^{s}}{\sum_{s=1}^{4} N_{j t}^{s}}
$$

Note that the explanatory variables are in proportions and so $\sum_{s=1}^{4} \Delta P_{j t}^{s}=0$. We therefore have to exclude one of the skill groups in each of the regressions. In addition, we include a vector of worker characteristics (measured at $t-1$ ), $\mathbf{x}_{i, t-1}$ to capture other influences on the probability of promotion. If observably "better" workers select into industries with faster rates of skill upgrading, the correlation between career mobility and industry upgrading rates might be spurious. The empirical literature on occupational mobility provides us with some guidance as to what $\mathbf{x}_{i, t-1}$ should contain. Sicherman \& Galor (1990), for example, derive and estimate a model in which the level of schooling, experience and duration in occupation are important influences. Our basic specification includes age, tenure with current employer and years of education, as well as gender, marital status, union status, health and current hourly wage. Table 8 provides summary statistics for all explanatory variables.

The most noticeable difference between the two samples is in the distribution of years of education; the BHPS sample has a much higher proportion with less than 12 years of education. The BHPS sample is also slightly older and has rather fewer children. Note also that it is not possible to determine the length of time an individual has been working for their current employer in the BHPS if they started working for them before the start of the panel in 1991. We therefore use length of time in current position as a proxy.

We also include a full set of industry dummies $\mathbf{I}_{j}$. This means that we are identifying the effect of skill upgrading on the probability of promotion via within-industry 
Table 8: Explanatory variables: descriptive statistics

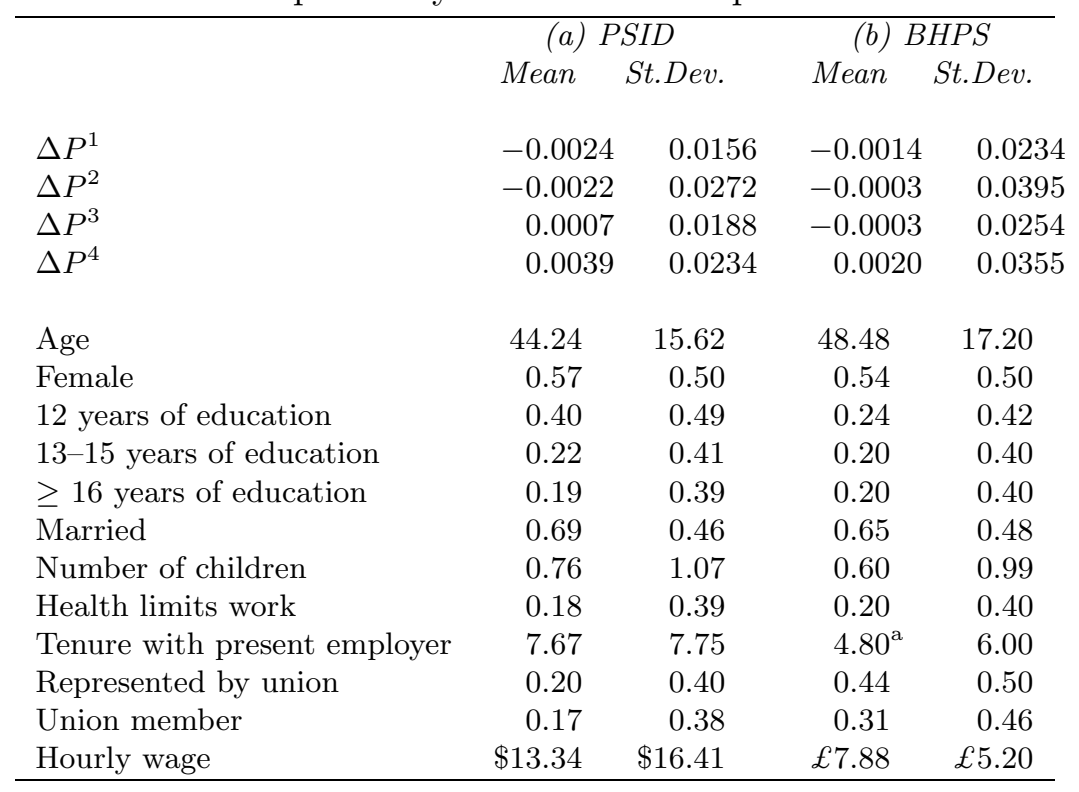

a Tenure in current position with present employer.

changes in $\Delta P_{j t}^{s}$. It may be that some industries have a higher propensity both for skill upgrading and for occupational mobility, although the two are not necessarily correlated.

Equation (3) is the probability of moving down the skill ladder, and is specified in exactly the same way as (2). Equation (4) is the probability of exiting employment between $t-1$ and $t$. This is defined as having a skill group of 0 at $t$ conditional on having a positive skill group at $t-1 .^{10}$

In each model the parameters of particular interest are $\boldsymbol{\beta}^{s}$, the estimated impact of changes in the size of skill groups on movement probabilities. A change in the relative size of a skill group can be accommodated by a change in the relative rates of promotion, demotion or entry and exit. Models (2)-(4) allow us to quantify the relative importance of each of these routes, while controlling for individual characteristics and skill levels.

In Table 9 we report the marginal effects associated with the estimates of $\boldsymbol{\beta}_{\text {up }}$ from model (2). The first panel shows the "raw" effect i.e.the estimates of model (2) with $\mathbf{x}_{i, t-1}$ and $\mathbf{I}_{j}$ excluded. The second panel gives results with the $\mathbf{I}_{j}$ included, and the third panel with both $\mathbf{x}_{i, t-1}$ and $\mathbf{I}_{j}$ included. We report marginal effects because

\footnotetext{
${ }^{10}$ Skill group "0" comprises all labour market states apart from employment, including unemployment, self-employment, retirement, ill-health and education. In the PSID the most common exit state from employment is unemployment; in the BHPS rather more exit into retirement and ill-health.
} 
these are non-linear probability models.

Table 9: Estimates of probability of promotion ${ }^{\mathrm{a}}$

\begin{tabular}{|c|c|c|c|c|c|c|}
\hline & \multicolumn{3}{|c|}{ (a) PSID } & \multicolumn{3}{|c|}{ (b) $B H P S$} \\
\hline & \multicolumn{3}{|c|}{ Skill group at $t-1$} & \multicolumn{3}{|c|}{ Skill group at $t-1$} \\
\hline & 1 & 2 & 3 & 1 & 2 & 3 \\
\hline \multicolumn{7}{|c|}{ Raw effect } \\
\hline$\Delta P_{j t}^{1}$ & & $\begin{array}{r}-0.5761 \\
{[0.001]}\end{array}$ & $\begin{array}{c}-0.1004 \\
{[0.781]}\end{array}$ & & $\begin{array}{c}0.0402 \\
{[0.742]}\end{array}$ & $\begin{array}{r}0.4827 \\
{[0.338]}\end{array}$ \\
\hline \multirow[t]{2}{*}{$\Delta P_{j t}^{2}$} & 2.0038 & & -0.0530 & 0.7843 & & -0.1860 \\
\hline & {$[0.000]$} & & [0.829] & {$[0.019]$} & & {$[0.358]$} \\
\hline \multirow[t]{2}{*}{$\Delta P_{j t}^{3}$} & 1.8944 & 0.4708 & & 0.5452 & 0.2832 & \\
\hline & {$[0.007]$} & {$[0.001]$} & & {$[0.262]$} & {$[0.028]$} & \\
\hline \multirow[t]{2}{*}{$\Delta P_{j t}^{4}$} & 2.2132 & 0.3105 & 0.8099 & 0.4462 & 0.1823 & 0.2271 \\
\hline & {$[0.000]$} & {$[0.006]$} & {$[0.001]$} & [0.229] & {$[0.031]$} & {$[0.181]$} \\
\hline \multicolumn{7}{|c|}{ Industry fixed-effects } \\
\hline \multirow[t]{2}{*}{$\Delta P_{j t}^{1}$} & & -0.3737 & 0.0684 & & -0.0674 & 0.2323 \\
\hline & & {$[0.023]$} & {$[0.821]$} & & {$[0.610]$} & [0.593] \\
\hline \multirow[t]{2}{*}{$\Delta P_{j t}^{2}$} & 2.1006 & & 0.0735 & 0.7799 & & 0.1108 \\
\hline & {$[0.000]$} & & {$[0.730]$} & {$[0.024]$} & & {$[0.581]$} \\
\hline \multirow[t]{2}{*}{$\Delta P_{j t}^{3}$} & 2.3593 & 0.5112 & & 0.4588 & 0.2701 & \\
\hline & {$[0.001]$} & {$[0.000]$} & & {$[0.377]$} & {$[0.019]$} & \\
\hline \multirow[t]{2}{*}{$\Delta P_{j t}^{4}$} & 2.5035 & 0.2991 & 0.7011 & 0.5022 & 0.1375 & 0.5522 \\
\hline & {$[0.000]$} & {$[0.006]$} & {$[0.002]$} & {$[0.208]$} & {$[0.091]$} & {$[0.007]$} \\
\hline \multicolumn{7}{|c|}{ All covariates } \\
\hline \multirow[t]{2}{*}{$\Delta P_{j t}^{1}$} & & -0.3706 & 0.0360 & & -0.0357 & 0.2780 \\
\hline & & {$[0.018]$} & {$[0.901]$} & & {$[0.775]$} & {$[0.512]$} \\
\hline \multirow[t]{2}{*}{$\Delta P_{j t}^{2}$} & 1.9909 & & 0.1024 & 0.7043 & & 0.0983 \\
\hline & {$[0.000]$} & & {$[0.618]$} & {$[0.049]$} & & {$[0.613]$} \\
\hline \multirow[t]{2}{*}{$\Delta P_{j t}^{3}$} & 2.3027 & 0.5102 & & 0.4246 & 0.2563 & \\
\hline & {$[0.002]$} & {$[0.000]$} & & {$[0.417]$} & {$[0.020]$} & \\
\hline \multirow[t]{2}{*}{$\Delta P_{j t}^{4}$} & 2.3538 & 0.2729 & 0.6969 & 0.3930 & 0.1384 & 0.6089 \\
\hline & {$[0.000]$} & {$[0.008]$} & {$[0.002]$} & {$[0.337]$} & {$[0.074]$} & {$[0.002]$} \\
\hline
\end{tabular}

${ }^{a}$ Robust $p$-values in brackets.

The first point to note is that estimates of $\boldsymbol{\beta}_{\text {up }}$ appear robust to the inclusion of industry fixed effects and individual covariates. This suggests that the correlation between the speed of skill upgrading and the probability of promotion is not being caused either by a correlation with industry fixed effects or a correlation with the individual characteristics of workers in those industries.

We therefore focus on the third panel of Table 9. We find that a higher rate of increase in the proportion of employment in higher skill groups significantly increases the probability that an individual is promoted. In other words, an individual working in industry $j$ in skill group $s$ is more likely to be promoted if industry $j$ is expanding its employment of workers in skill groups above $s$. This result is confirmed both in the PSID and the BHPS, although the estimated marginal effects for the PSID are 
in every case larger and more significant (a smaller $p$-value).

We should stress that this result is not occurring simply because the explanatory variables (the changes in the shares of each skill group in each industry) are created from aggregating up the individual-level data. As we noted in the introduction, changes in $\Delta P_{j t}^{s}$ can be achieved in a number of ways. For example, industries might expand the proportional size of skill group $s$ by hiring more workers from the same skill group in other industries; by hiring more workers from non-employment (such as from education), or by promoting more workers from lower skill groups. Furthermore, the proportional size of a skill group can also be increased by reducing outflows rather than increasing inflows. There are therefore several degrees of freedom in the relationship between the probability of promotion and the change in the proportional size of each skill group.

How large are these effects? The marginal effects reported refer to the slope of the estimated probability of promotion evaluated at the mean of $\Delta P_{j t}^{s}$. To determine the size of these effects one needs to consider how much the probability of promotion would change for a realistic change in $\Delta P_{j t}^{s}$. We therefore scale the marginal effects by the inter-quartile range of each explanatory variable. This gives us an estimate of how much the probability of promotion changes between an individual working in an industry with a slow rate of change and one with a fast rate of change. These scaled estimates are given in Table 10.

Table 10: Scaled estimates of promotion probabilities

\begin{tabular}{|c|c|c|c|c|}
\hline & $\operatorname{Pr}(u p)$ & $\Delta P_{j t}^{2}$ & $\Delta P_{j t}^{3}$ & $\Delta P_{j t}^{4}$ \\
\hline \multicolumn{5}{|c|}{ (a) PSID } \\
\hline 1 & 0.368 & 0.0553 & 0.0541 & 0.0707 \\
\hline 2 & 0.123 & & 0.0120 & 0.0082 \\
\hline 3 & 0.124 & & & 0.0209 \\
\hline \multicolumn{5}{|c|}{ (b) BHPS } \\
\hline 1 & 0.273 & 0.0319 & $L^{\mathrm{a}}$ & $L^{\mathrm{a}}$ \\
\hline 2 & 0.101 & & 0.0057 & 0.0052 \\
\hline 3 & 0.149 & & & 0.0229 \\
\hline
\end{tabular}

The baseline probability of promotion from skill group 1 is 0.368 (PSID) and 0.273 (BHPS). Working in an industry with a rate of skill upgrading at the top of the inter-quartile range rather than the bottom increases the probability of promotion by about 5.5 percentage points in the PSID and 3.2 in the BHPS. The effect is generally smaller for higher skill groups in absolute terms, but is still large in relative 
terms. The baseline probability of promotion from skill group 3 is 0.124 (PSID) and 0.149 (BHPS). This is increased by 0.0209 (PSID) and 0.0229 (BHPS), a substantial relative change.

Table 11: Estimates of probability of demotion

\begin{tabular}{|c|c|c|c|c|c|c|}
\hline & \multicolumn{3}{|c|}{ (a) PSID } & \multicolumn{3}{|c|}{ (b) $B H P S$} \\
\hline & \multicolumn{3}{|c|}{ Skill group at $t-1$} & \multicolumn{3}{|c|}{ Skill group at $t-1$} \\
\hline & 2 & 3 & 4 & 2 & 3 & 4 \\
\hline \multicolumn{7}{|c|}{ Raw effect } \\
\hline \multirow{2}{*}{$\Delta P_{j t}^{1}$} & 0.2397 & 0.4772 & 0.0604 & 0.2387 & 0.9217 & 0.6444 \\
\hline & {$[0.031]$} & {$[0.202]$} & {$[0.824]$} & {$[0.003]$} & {$[0.027]$} & {$[0.015]$} \\
\hline \multirow[t]{2}{*}{$\Delta P_{j t}^{2}$} & & 1.0203 & 0.2173 & & 0.4789 & 0.5561 \\
\hline & & {$[0.000]$} & {$[0.221]$} & & {$[0.011]$} & {$[0.000]$} \\
\hline \multirow[t]{2}{*}{$\Delta P_{j t}^{3}$} & -0.1563 & & 0.1699 & 0.0159 & & 0.2964 \\
\hline & {$[0.067]$} & & {$[0.475]$} & {$[0.817]$} & & [0.153] \\
\hline \multirow[t]{2}{*}{$\Delta P_{j t}^{4}$} & -0.0679 & 0.0677 & & -0.0146 & 0.1063 & \\
\hline & {$[0.329]$} & {$[0.790]$} & & {$[0.771]$} & {$[0.553]$} & \\
\hline \multicolumn{7}{|c|}{ Industry fixed-effects } \\
\hline \multirow[t]{2}{*}{$\Delta P_{j t}^{1}$} & 0.2268 & 0.4790 & 0.2399 & 0.1742 & 0.5222 & 0.4951 \\
\hline & {$[0.013]$} & {$[0.144]$} & {$[0.355]$} & {$[0.002]$} & {$[0.194]$} & {$[0.035]$} \\
\hline \multirow[t]{2}{*}{$\Delta P_{j t}^{2}$} & & 0.9530 & 0.1838 & & 0.5565 & 0.4583 \\
\hline & & {$[0.000]$} & {$[0.287]$} & & {$[0.004]$} & {$[0.001]$} \\
\hline \multirow[t]{2}{*}{$\Delta P_{j t}^{3}$} & -0.0751 & & 0.3663 & 0.0072 & & 0.2799 \\
\hline & {$[0.441]$} & & {$[0.106]$} & {$[0.920]$} & & {$[0.117]$} \\
\hline \multirow[t]{2}{*}{$\Delta P_{j t}^{4}$} & -0.0183 & 0.0994 & & -0.0089 & 0.3017 & \\
\hline & {$[0.792]$} & {$[0.686]$} & & [0.838] & {$[0.126]$} & \\
\hline \multicolumn{7}{|c|}{ All covariates } \\
\hline \multirow[t]{2}{*}{$\Delta P_{j t}^{1}$} & 0.2092 & 0.3814 & 0.1653 & 0.1395 & 0.3667 & 0.6017 \\
\hline & {$[0.011]$} & {$[0.196]$} & {$[0.515]$} & {$[0.003]$} & {$[0.313]$} & {$[0.008]$} \\
\hline \multirow[t]{2}{*}{$\Delta P_{j t}^{2}$} & & 0.8420 & 0.0788 & & 0.4721 & 0.4658 \\
\hline & & {$[0.000]$} & {$[0.643]$} & & {$[0.006]$} & {$[0.000]$} \\
\hline \multirow[t]{2}{*}{$\Delta P_{j t}^{3}$} & -0.0864 & & 0.2801 & 0.0117 & & 0.2950 \\
\hline & {$[0.323]$} & & {$[0.207]$} & {$[0.844]$} & & [0.095] \\
\hline \multirow[t]{2}{*}{$\Delta P_{j t}^{4}$} & -0.0197 & 0.1215 & & -0.0112 & 0.2516 & \\
\hline & {$[0.752]$} & {$[0.590]$} & & {$[0.760]$} & {$[0.139]$} & \\
\hline
\end{tabular}

In Table 11 we report the marginal effects of estimates of $\boldsymbol{\beta}_{\text {down }}$ from Equation (3). As before, those estimates which are significantly from zero appear quite robust to the inclusion of industry fixed effects (second column) and individual covariates (third column). Interestingly, we also find evidence of a "pull" effect from changes in the proportions of skill groups, but this time in a downward direction. A worker in skill group $s$ working in an industry which expands the size of skill group $s-1$ is significantly more likely to be demoted. In the PSID this is true for workers in skill groups 2 and 3 , but not in the top skill group. In the BHPS this is true for all skill groups. 
However, we do not find any evidence that skill upgrading per se increases the rate of individual demotion. As noted in the introduction, if the process of skill upgrading leads to lower skill jobs being destroyed, workers who held those jobs might be forced further down the skill ladder if they are unable to retrain. Empirically, this would mean that a worker at skill level $s$ would be more likely to be demoted if their industry was experiencing a higher rate of growth of skill groups $s+1, s+2$ and so on. The results in Table 11 show that this effect is always insignificant and in some cases wrongly signed.

Table 12: Scaled estimates of demotion probabilities

\begin{tabular}{|c|c|c|c|c|}
\hline & lown) & $\Delta P_{j t}^{1}$ & $\Delta P_{j t}^{2}$ & $\Delta P_{j t}^{3}$ \\
\hline \multicolumn{5}{|c|}{ (a) PSID } \\
\hline 2 & 0.050 & \multirow[t]{3}{*}{0.0032} & \multirow{3}{*}{0.0234} & \\
\hline 3 & 0.142 & & & \\
\hline 4 & 0.181 & & & $-^{\mathrm{a}}$ \\
\hline \multicolumn{5}{|c|}{ (b) $B H P S$} \\
\hline 2 & 0.028 & \multirow[t]{3}{*}{0.0031} & & \\
\hline 3 & 0.144 & & 0.0214 & \\
\hline 4 & 0.150 & & & 0.0065 \\
\hline
\end{tabular}

As before, these results need to be scaled by some range within the data to get an idea how large the effect is, shown in Table 12. Although the absolute size of the effect is generally smaller than the promotion effect, relative to the baseline probability the effect can be quite large. An average worker in skill level 3 has a baseline probability of demotion of 0.142 (PSID) and 0.144 (BHPS). In both samples this probability is 0.02 greater in industries with high rates of growth of skill group 2. These results do not support the hypothesis that industry-level skill upgrading causes higher rates of individual demotion. Nevertheless, they do reveal that worker mobility does respond significantly to changes in employment proportions, both in an upward and a downward direction.

Given the strong relationship between skill upgrading and worker promotion and demotion, it seems less likely that changes in the sizes of skill groups will have a large effect on the rate at which workers leave employment. This is confirmed by the results in Table 13, which report marginal effects of estimates of $\boldsymbol{\beta}_{\text {out }}$ from Equation (4). In both countries we can find few significant relationships between 
any of the explanatory variables and the rate of exit. ${ }^{11}$ This implies that a worker in skill group $s$ does not suffer a greater likelihood of exiting employment if their industry has a higher rate of growth of skill groups $s+1, s+2$ and so on.

Table 13: Estimates of probability of exiting employment ${ }^{\mathrm{a}}$

\begin{tabular}{|c|c|c|c|c|c|c|c|c|}
\hline & & (a) & $\overline{S I D}$ & & & (b) 1 & $H P S$ & \\
\hline & & Skill grov & at $t-1$ & & & Skill grou & at $t-1$ & \\
\hline & 1 & 2 & 3 & 4 & 1 & 2 & 3 & 4 \\
\hline All co & ariates & & & & & & & \\
\hline$\Delta P_{j t}^{1}$ & & -0.0933 & 0.3418 & -0.0487 & -0.0380 & 0.0399 & 0.0148 & -0.0294 \\
\hline & & {$[0.523]$} & {$[0.197]$} & {$[0.772]$} & {$[0.870]$} & {$[0.716]$} & {$[0.959]$} & {$[0.850]$} \\
\hline$\Delta P_{j t}^{2}$ & 0.3050 & & 0.1208 & 0.1721 & 0.2242 & & 0.2366 & 0.0654 \\
\hline & [0.328] & & {$[0.532]$} & {$[0.125]$} & {$[0.546]$} & & {$[0.088]$} & {$[0.479]$} \\
\hline$\Delta P_{j t}^{3}$ & 0.9293 & 0.0372 & & 0.0573 & 0.1381 & 0.1801 & & 0.1947 \\
\hline & {$[0.049]$} & {$[0.774]$} & & [0.698] & [0.591] & {$[0.127]$} & & [0.131] \\
\hline$\Delta P_{j t}^{4}$ & 0.5964 & 0.0888 & 0.1026 & & & 0.1502 & 0.1516 & \\
\hline & {$[0.113]$} & {$[0.341]$} & {$[0.607]$} & & & {$[0.039]$} & {$[0.284]$} & \\
\hline
\end{tabular}

${ }^{a}$ These estimates refer to the combined probability of exiting employment to any nonemployment labour market state; including unemployment, retirement and self-employment.

Returning to the first question posed at the beginning of this section, these results suggest that the speed of skill upgrading does indeed contribute to a greater upward mobility of workers rather than increased rates of demotion or job loss.

\section{Within- and between-firm mobility}

Our conclusion that firms increase the proportion of more highly skilled workers by taking on more workers from lower skill groups (and hence increasing the rate of promotion) would be strengthened if we could show that this process occurred predominantly within rather than between firms.

In Table 14 we report estimates of the probability of promotion separately for those workers who stay in the same firm and those workers who change firm. All these estimates include a full set of covariates and industry dummies, and therefore can be compared to the third panel of Tables 9 .

The results are generally supportive of the hypothesis that the effect of skill upgrading on the probability of promotion comes through within firm moves. In the PSID sample all of the significant effects reported in Table 9 are also significant for within firm moves, and all but two are insignificant for between firm moves. Note also that

\footnotetext{
${ }^{11}$ In the Multinomial Logit estimates reported in Appendix B we find some evidence that skill upgrading does cause an increased probability of exiting employment, particularly for the bottom skill group in the PSID. However, the size of the marginal effects are far smaller than those on the probability of promotion, and so our conclusion still holds.
} 
Table 14: Estimates of probability of promotion: within and between firms

\begin{tabular}{|c|c|c|c|c|c|c|}
\hline & \multicolumn{3}{|c|}{ (a) PSID } & \multicolumn{3}{|c|}{ (b) $B H P S$} \\
\hline & \multicolumn{3}{|c|}{ Skill group at $t-1$} & \multicolumn{3}{|c|}{ Skill group at $t-1$} \\
\hline & 1 & 2 & 3 & 1 & 2 & 3 \\
\hline \multicolumn{7}{|c|}{ Within firms } \\
\hline \multirow[t]{2}{*}{$\Delta P_{j t}^{1}$} & & -0.1699 & 0.0999 & & 0.0182 & 0.3173 \\
\hline & & {$[0.215]$} & {$[0.693]$} & & {$[0.874]$} & {$[0.420]$} \\
\hline \multirow[t]{2}{*}{$\Delta P_{j t}^{2}$} & 1.6327 & & 0.0386 & 0.1156 & & 0.1569 \\
\hline & {$[0.000]$} & & {$[0.828]$} & [0.719] & & [0.391] \\
\hline \multirow[t]{2}{*}{$\Delta P_{j t}^{3}$} & 2.1964 & 0.2906 & & 0.2135 & 0.2461 & \\
\hline & {$[0.001]$} & {$[0.010]$} & & {$[0.645]$} & {$[0.012]$} & \\
\hline \multirow[t]{2}{*}{$\Delta P_{j t}^{4}$} & 2.0337 & 0.1858 & 0.5507 & -0.1101 & 0.1768 & 0.5938 \\
\hline & {$[0.000]$} & {$[0.039]$} & {$[0.003]$} & {$[0.762]$} & {$[0.011]$} & {$[0.001]$} \\
\hline \multicolumn{7}{|c|}{ Between firms } \\
\hline \multirow[t]{2}{*}{$\Delta P_{j t}^{1}$} & & -0.1398 & -0.0547 & & -0.0384 & -0.0270 \\
\hline & & {$[0.013]$} & {$[0.579]$} & & {$[0.317]$} & {$[0.758]$} \\
\hline \multirow[t]{2}{*}{$\Delta P_{j t}^{2}$} & 0.2309 & & 0.0558 & 0.3400 & & -0.0385 \\
\hline & {$[0.301]$} & & {$[0.475]$} & {$[0.018]$} & & {$[0.342]$} \\
\hline \multirow[t]{2}{*}{$\Delta P_{j t}^{3}$} & 0.0703 & 0.1505 & & -0.0355 & 0.0052 & \\
\hline & {$[0.840]$} & {$[0.001]$} & & {$[0.888]$} & [0.893] & \\
\hline \multirow{2}{*}{$\Delta P_{j t}^{4}$} & 0.2280 & 0.0432 & 0.0585 & 0.2857 & -0.0270 & 0.0012 \\
\hline & [0.388] & {$[0.238]$} & {$[0.494]$} & [0.098] & {$[0.284]$} & {$[0.977]$} \\
\hline
\end{tabular}

the size of the marginal effects are in every case larger for within than between firm moves.

In the BHPS sample we get precisely the same result for skill groups 2 and 3: within firm moves are significantly affected by skill upgrading while between firm moves are not. The only exception is in skill group 1 , where the overall effect seems to come through more strongly from between than within firm moves.

\section{Individual characteristics and industry demand}

Thus far we have concentrated solely on the impact of changing employment shares on the probability of moves up and down the skill ladder. But how important are these influences relative to the personal and workplace characteristics of the individuals concerned?

\section{(a) Promotion}

Table 15 reports the marginal effects of estimates of $\gamma_{\text {up }}$ for Model (2), the probability of promotion. The results indicate considerable consistency in effect across 
countries. In no cases do we find a sign disagreement where the coefficient estimate is significantly different zero at the $10 \%$ level in both countries. This indicates that similar processes underly the promotion process in both countries, and gives us some confidence in the robustness of our results.

Table 15: Marginal effects of worker characteristics on probability of promotion

Skill group $1 \quad$ Skill group $2 \quad$ Skill group 3

\begin{tabular}{lrlrlrl} 
(a) PSID & \multicolumn{7}{c}{} & & & & \\
& & & & & & \\
Age & -0.0044 & {$[0.478]$} & 0.0020 & {$[0.256]$} & 0.0016 & {$[0.618]$} \\
Age $^{2} \times 100$ & -0.0010 & {$[0.890]$} & -0.0048 & {$[0.032]$} & -0.0031 & {$[0.422]$} \\
Female & -0.0293 & {$[0.229]$} & 0.0357 & {$[0.000]$} & -0.0274 & {$[0.011]$} \\
12 years of education & 0.0155 & {$[0.538]$} & 0.0504 & {$[0.000]$} & 0.0316 & {$[0.220]$} \\
$13-15$ years of education & 0.1174 & {$[0.001]$} & 0.1148 & {$[0.000]$} & 0.0610 & {$[0.022]$} \\
$\geq 16$ years of education & 0.1720 & {$[0.017]$} & 0.2539 & {$[0.000]$} & 0.1279 & {$[0.000]$} \\
Married & 0.0013 & {$[0.955]$} & 0.0138 & {$[0.015]$} & 0.0218 & {$[0.019]$} \\
Number of children & -0.0138 & {$[0.229]$} & -0.0040 & {$[0.144]$} & -0.0148 & {$[0.001]$} \\
Health limits work & -0.0518 & {$[0.147]$} & 0.0102 & {$[0.296]$} & -0.0114 & {$[0.434]$} \\
Tenure with current employer & -0.0154 & {$[0.000]$} & -0.0031 & {$[0.002]$} & -0.0033 & {$[0.067]$} \\
Tenure ${ }^{2} \times 100$ & 0.0548 & {$[0.000]$} & 0.0136 & {$[0.000]$} & 0.0109 & {$[0.106]$} \\
Represented by union & -0.1061 & {$[0.039]$} & -0.0280 & {$[0.046]$} & 0.0027 & {$[0.915]$} \\
Union member & -0.0388 & {$[0.487]$} & -0.0388 & {$[0.009]$} & -0.0167 & {$[0.522]$} \\
Hourly wage & 0.0117 & {$[0.001]$} & 0.0006 & {$[0.070]$} & 0.0003 & {$[0.228]$}
\end{tabular}

(b) $B H P S$

$\begin{array}{lrlrlrl}\text { Age } & 0.0017 & {[0.814]} & -0.0020 & {[0.318]} & 0.0096 & {[0.065]} \\ \text { Age }^{2} \times 100 & -0.0100 & {[0.212]} & 0.0019 & {[0.448]} & -0.0134 & {[0.038]} \\ \text { Female } & -0.0751 & {[0.015]} & -0.0024 & {[0.761]} & -0.0546 & {[0.001]} \\ 12 \text { years of education } & -0.0389 & {[0.264]} & 0.0340 & {[0.000]} & 0.0022 & {[0.939]} \\ 13-15 \text { years of education } & 0.0510 & {[0.240]} & 0.0705 & {[0.000]} & 0.0139 & {[0.624]} \\ \geq 16 \text { years of education } & -0.0205 & {[0.723]} & 0.1267 & {[0.000]} & 0.0246 & {[0.385]} \\ \text { Married } & -0.0327 & {[0.302]} & -0.0070 & {[0.318]} & -0.0072 & {[0.654]} \\ \text { Number of children } & -0.0011 & {[0.944]} & -0.0092 & {[0.006]} & -0.0141 & {[0.087]} \\ \text { Health limits work } & -0.0375 & {[0.379]} & -0.0074 & {[0.449]} & -0.0264 & {[0.288]} \\ \text { Tenure with current employer } & -0.0042 & {[0.349]} & -0.0056 & {[0.000]} & -0.0105 & {[0.001]} \\ \text { Tenure }{ }^{2} \times 100 & 0.0044 & {[0.756]} & 0.0149 & {[0.001]} & 0.0244 & {[0.079]} \\ \text { Represented by union } & 0.0455 & {[0.251]} & 0.0036 & {[0.656]} & 0.0347 & {[0.084]} \\ \text { Union member } & -0.0403 & {[0.356]} & -0.0254 & {[0.004]} & -0.0320 & {[0.118]} \\ \text { Hourly wage } & 0.0068 & {[0.320]} & 0.0099 & {[0.000]} & 0.0043 & {[0.004]}\end{array}$

In the US, education has a monotonically increasing impact on the probability of promotion for all skill groups. Workers with 13-15 years of education are 11-12\% more likely of being promoted from skill groups 1 and 2 , and $6 \%$ more likely of being promoted from skill group 3, than someone with less than 12 years of education. Those with university degrees or equivalent face an even more favourable situation, with promotion probabilities 13-25\% higher than those with base level qualifications.

In the UK the pattern is less pronounced, with the positive impact of education being 
restricted to those in skill group 2. Qualitatively the impact is also smaller, with those having university level qualifications facing promotion prospects $13 \%$ higher than the base group.

Personal characteristics also prove to be important in determining the probability of promotion. In general women face worse promotion prospects than men, being less likely to be promoted into the top skill group and out of the bottom skill group in both countries. An exception to this occurs in skill group 2 in the US, where women's promotion prospects appear to be more favourable.

Family circumstances also prove to be an important determinant of promotion prospects in both countries. The number of children always attracts a negative coefficient, although this appears only to be statistically significant when promotions from higher skill categories are considered. In contrast marriage proves to be beneficial to employment prospects in the US, though no similar effect is observable for the UK.

Other personal characteristics prove to be relatively unimportant. Within skill groups, the age of the individual has no statistically significant impact and, although the impact of health problems on promotion prospects is everywhere negative, it is never statistically significant.

If we now consider differing aspects of workplace organisation, there is evidence that union organisation has a negative impacts on the probability of promotion. In both countries union members are less likely to be promoted from skill group 2 and in the US union presence inhibits promotion from skill groups 1 and 2. The direction of causality might be questioned for these variables however if those with lower promotion prospects join the union for employment protection reasons.

We find that workers with higher levels of tenure are less likely to be promoted in both countries. At first glance this appears surprising, because it suggests that someone is most likely to be promoted immediately on joining a firm. Although the tenure effect becomes positive again after 11-14 years in PSID, no turning point is apparent in the BHPS results. To investigate this effect further we compared the impact of tenure on within and between firm movements. As expected, for within firm movement the tenure variable attracts a positive coefficient, so promotion becomes more likely over time. The overall negative impact reflects the general effect of matching which slows all moves including promotion. In our data this latter effect dominates.

Finally those individuals with higher hourly wages are more likely to be promoted. Within skill group, a higher wage is likely to reflect both a high firm worker match 
and higher unobserved worker quality. This is statistically significant for skill groups 1 and 2 in the US and 2 and 3 in the UK.

\section{(b) Demotion}

Table 16 presents analogous results to Table 15, but for the probability of demotion. Once again there is a strong consistency in our findings across countries. In both the US and the UK the importance of educational background on employment prospects is apparent. Higher levels of education reduce the likelihood of demotion. Quantitatively the impact of education on demotion is however somewhat smaller than its impact on promotion. Educational qualifications higher than the base reduce the probability of demotion by between 0.7 and $2.3 \%$ for skill group 1 in the US and between 1-2\% for the UK. For higher skill groups the effect is quantitatively larger, though the effect only shows through for those with the higher levels of education in skill groups 3 and 4 . This may however simply reflect the low number of individuals in these categories with low educational levels, which make the effect hard to determine statistically.

The impact of gender on the probability of demotion is rather more complicated than that for promotion. In the UK, those women in higher skill levels are more likely to be demoted than males but less likely to be demoted from skill group 1 . In the US women fair comparatively better, being less likely to be demoted from skill groups 1 and 2 .

In general, those family circumstances which made an individual less likely to be promoted also make the individual more likely to be demoted. Marriage improves employment prospects, whereas having more children make an individual more likely to face an adverse downward movement, though these effects are limited to the lower skill groups. In skill group 4, family circumstances are statistically insignificant in both countries.

As with the promotion probabilities, tenure appears to reflect the increasing average quality of match. Hence those with high levels of tenure are less likely be demoted. This effect may also be reflected in the negative coefficient associated with age in the PSID sample. In contrast, higher hourly wages, which reflect both better match quality and higher levels of unobserved worker quality, are associated with a lower likelihood of demotion.

What is perhaps most striking about the results from Tables 15 and 16 is that the marginal effects associated with individual characteristics are not in general much 
Table 16: Marginal effects of worker characteristics on probability of demotion

\begin{tabular}{|c|c|c|c|c|c|c|}
\hline \multirow{2}{*}{ (a) $P S I D$} & \multicolumn{2}{|c|}{ Skill group 2} & \multicolumn{2}{|c|}{ Skill group 3} & \multicolumn{2}{|c|}{ Skill group 4} \\
\hline & & & & & & \\
\hline Age & 0.0006 & {$[0.522]$} & -0.0067 & [0.038] & -0.0058 & {$[0.082]$} \\
\hline $\mathrm{Age}^{2} \times 100$ & -0.0005 & {$[0.630]$} & 0.0067 & {$[0.095]$} & 0.0069 & {$[0.077]$} \\
\hline Female & -0.0365 & {$[0.000]$} & -0.0241 & {$[0.044]$} & 0.0143 & {$[0.200$} \\
\hline 12 years of education & -0.0068 & {$[0.096]$} & 0.0081 & {$[0.681]$} & -0.0341 & {$[0.178]$} \\
\hline $13-15$ years of education & -0.0214 & {$[0.000]$} & -0.0187 & {$[0.349]$} & -0.0777 & {$[0.001]$} \\
\hline$\geq 16$ years of education & -0.0234 & {$[0.000]$} & -0.0776 & {$[0.000]$} & -0.2115 & {$[0.000]$} \\
\hline Married & -0.0133 & {$[0.000]$} & -0.0147 & {$[0.137]$} & -0.0148 & {$[0.171]$} \\
\hline Number of children & -0.0006 & {$[0.692]$} & 0.0099 & {$[0.026]$} & -0.0041 & {$[0.366]$} \\
\hline Health limits work & -0.0104 & {$[0.042]$} & -0.0002 & {$[0.990]$} & 0.0011 & {$[0.947]$} \\
\hline Tenure with current employer & -0.0019 & {$[0.001]$} & -0.0020 & {$[0.222]$} & -0.0028 & {$[0.094]$} \\
\hline Tenure $^{2} \times 100$ & 0.0052 & {$[0.006]$} & 0.0088 & {$[0.141]$} & 0.0073 & {$[0.219]$} \\
\hline Represented by union & 0.0072 & {$[0.383]$} & 0.0068 & {$[0.801]$} & 0.0141 & {$[0.621]$} \\
\hline Union member & 0.0099 & {$[0.264]$} & 0.0285 & {$[0.361]$} & -0.0018 & {$[0.952]$} \\
\hline Hourly wage & -0.0036 & {$[0.000]$} & -0.0070 & {$[0.000]$} & -0.0029 & {$[0.042]$} \\
\hline (b) $B H P S$ & & & & & & \\
\hline Age & -0.0008 & {$[0.423]$} & 0.0015 & {$[0.749]$} & -0.0033 & {$[0.409]$} \\
\hline $\mathrm{Age}^{2} \times 100$ & 0.0008 & {$[0.499]$} & -0.0012 & {$[0.840]$} & 0.0030 & {$[0.544]$} \\
\hline Female & -0.0081 & {$[0.027]$} & 0.0352 & {$[0.019]$} & 0.0319 & {$[0.006]$} \\
\hline 12 years of education & -0.0119 & {$[0.001]$} & -0.0219 & {$[0.332]$} & -0.0176 & {$[0.353]$} \\
\hline $13-15$ years of education & -0.0195 & {$[0.000]$} & -0.0268 & {$[0.230]$} & -0.0429 & {$[0.021]$} \\
\hline$\geq 16$ years of education & -0.0109 & {$[0.008]$} & -0.0880 & {$[0.000]$} & -0.0980 & {$[0.000$} \\
\hline Married & -0.0093 & {$[0.011]$} & -0.0372 & {$[0.012]$} & 0.0174 & {$[0.124]$} \\
\hline Number of children & 0.0051 & {$[0.001]$} & 0.0214 & {$[0.004]$} & 0.0019 & {$[0.724]$} \\
\hline Health limits work & -0.0092 & {$[0.043]$} & 0.0152 & {$[0.523]$} & 0.0129 & {$[0.568]$} \\
\hline Tenure with current employer & -0.0010 & {$[0.079]$} & -0.0009 & {$[0.732]$} & -0.0023 & {$[0.252]$} \\
\hline Tenure $^{2} \times 100$ & 0.0033 & {$[0.095]$} & -0.0051 & {$[0.678]$} & 0.0044 & {$[0.622]$} \\
\hline Represented by union & 0.0114 & {$[0.004]$} & 0.0351 & {$[0.045]$} & 0.0143 & {$[0.314]$} \\
\hline Union member & -0.0032 & {$[0.457]$} & -0.0196 & {$[0.285]$} & -0.0126 & {$[0.393$} \\
\hline Hourly wage & -0.0046 & {$[0.000]$} & -0.0136 & {$[0.000]$} & -0.0091 & {$[0.000]$} \\
\hline
\end{tabular}

larger than those associated with the changes in industry measures of skill upgrading reported earlier, with the exception of time in education. This confirms that skill upgrading may be a quantitatively important component of occupational mobility.

\section{Conclusions}

In this paper we have used comparable individual level panel datasets for the US and UK to examine how industry level shifts in the demand for different types of workers has impacted on the occupational mobility of individual workers. Both countries have experienced substantial skill upgrading over the period considered, reducing the proportion in elementary occupations and increasing the proportion in technical, associate professional and professional grades. However the extent of upgrading across industries has differed in its level and in its timing. Thus, the use 
of parallel datasets has allowed us to explore the robustness of our results across separate labour markets facing different patterns of upgrading.

For both countries we find very high rates of movement up occupational ladders with, for example, between $20 \%$ and $25 \%$ of workers moving from skill level 1 to skill level 2 within a year. However, perhaps more surprisingly, we find that demotion rates are also large. Despite the presence of some measurement error, we find convincing evidence to suggest that such measured flows reflect genuine phenomena however. Demotions are associated with wages losses of between 18\%-25\% in the US and $17 \%-22 \%$ in the UK, with those moving employer suffering additional falls. Workers who move up skill ladders, by contrast, gain to the tune of $9 \%-21 \%$ in the US and $8 \%-21 \%$ in the UK.

We then examine the link between skill upgrading and the occupational mobility. In particular we assess whether the changing aggregate structure of the labour market encourages upward occupational mobility or whether it causes career interruption and dislocation. We find strong evidence to support the former view. An increase in the proportion of workers in higher skill groups significantly increases the probability that an individual will be promoted. This effect is also quantitatively large. A worker facing a rate of upgrading at the 75 th percentile is $5 \%$ more likely to be promoted that an equivalent worker at the 25th percentile in the US, and $3.5 \%$ more likely in the UK. By contrast, we find no evidence that skill upgrading increases the rate of individual demotion or dislocation.

Our results suggest that a faster rate of skill upgrading offers workers a "ladder" with which to climb to higher points on the occupational scale rather than pushing them down a "snake" to a lower skill group or to non-employment.

These results are only preliminary. More work needs to be done to verify the robustness of these results to (a) the definitions of skill groups, promotion and demotion; (b) the measures of skill upgrading used and (c) the econometric modelling of the process of movement. 


\section{References}

Bartel, A. \& Sicherman, N. (1998), "Technological change and the skill acquisition of young workers", Journal of Labor Economics 16, 718-755.

Berman, E., Bound, J. \& Griliches, Z. (1994), "Changes in the demand for skilled labour within U.S. manufacturing: evidence from the annual survey of manufactures", Quarterly Journal of Economics 109, 367-397.

Berman, E., Bound, J. \& Machin, S. (1998), "Implications of skill-biased technological change: international evidence", Quarterly Journal of Economics 113, 12451280 .

Card, D. \& DiNardo, J. (2002), "Skill-biased technological change and rising wage inequality: some problems and puzzles", Journal of Labor Economics 20, 733783.

Dunne, T., Haltiwanger, J. \& Troske, K. (1997), "Technology and jobs: secular changes and cyclical dynamics", Carnegie-Rochester Conference Series on Public Policy 46, 107-178.

Elias, P., McKnight, A. \& Kingshott, G. (1999), "Redefining skill: revision of the Standard Occupational Classification", Department for Employment and Education Skills Task Force Research Paper 19.

Farber, H. (1999), "Mobility and stability: the dynamics of job change in labor markets", in O. Ashenfelter \& D. Card, eds, Handbook of Labor Economics, Vol. 3B, Amsterdam: North-Holland, chapter 37, pp. 2439-2483.

Gibbons, R. \& Waldman, M. (1999), "Careers in organizations: Theory and evidence", in O. Ashenfelter \& D. Card, eds, Handbook of Labor Economics, Vol. 3, North-Holland, pp. 2373-2437.

Haskel, J. \& Heden, Y. (1999), "Computers and the demand for skilled labour: industry- and establishment-level panel evidence for the UK", The Economic Journal 109, C68-C79.

Hofferth, S., Stafford, F., Yeung, W.-J., Duncan, G., Lepkowski, J. \& Morgan, J. (1998), "Panel Study of Income Dynamics: Procedures and Codebooks", Institute for Social Research, University of Michigan.

International Labour Office (1990), ISCO-88: International Standard Classification of Occupations, Geneva:ILO.

Jovanovic, B. (1979a), "Firm specific capital and turnover", Journal of Political Economy 87, 1246-1259.

Jovanovic, B. (1979b), "Job matching and the theory of turnover", Journal of Political Economy 87, 972-990. 
Machin, S. (2001), "The changing nature of labour demand in the new economy and skill-biased technological change", Oxford Bulletin of Economics and Statistics 63, 753-776.

Mayhew, K. \& Roswell, B. (1981), "Occupational mobility in Britain", Oxford Bulletin of Economics and Statistics 43, 225-255.

Mortensen, D. \& Pissarides, C. (1998), "Technological progress, job creation and job destruction", Review of Economic Dynamics 1, 733-753.

Murphy, K. M. \& Welch, F. (1993), "Occupational change and the demand for skill 1940-1990", aer 83(2), 122-126.

Nickell, S. (1982), "The determinants of occupational success in Britain", Review of Economic Studies 49, 43-53.

Sicherman, N. \& Galor, O. (1990), "A theory of career mobility", Journal of Political Economy 98, 169-192.

Taylor, M., Brice, J., Buck, N. \& Prentice-Lane, E. (2003), "British Household Panel Survey User Manual Volume A: Introduction, Technical Report and Appendices", Colchester: University of Essex.

Wise, D. (1975), "Personal attributes, job performance and probability of promotion", Econometrica 43, 913-931. 


\section{Appendix A List of occupations}

The following table lists the most commonly occurring occupations in each skill group listed in order of frequency. The occupations listed account for $75 \%$ of employment in each skill group. The PSID occupational descriptions are from the 1970 US Census Bureau standard occupational classification. See Hofferth et al. (1998) for a full set of codes. The BHPS occupational descriptions are from the 1980 UK standard occupational classification. See Taylor et al. (2003) for a full set of codes.

Occupations in each ISCO skill group, UK and US

\begin{tabular}{|c|c|}
\hline (a) $P S I D$ & (b) $B H P S$ \\
\hline \multicolumn{2}{|l|}{ Skill group 1} \\
\hline Janitors \& sextons & Cleaners, domestics \\
\hline Cleaners \& charwomen & Packers, bottlers, canners, fillers \\
\hline Deliverymen \& routemen & Kitchen porters, hands \\
\hline Freight \& material handlers & Caretakers \\
\hline $\begin{array}{l}\text { Construction laborers, except carpen- } \\
\text { ters' helpers }\end{array}$ & All other labourers \& related workers \\
\hline Stock handlers & Farm workers \\
\hline $\begin{array}{l}\text { Gardeners \& groundskeepers, except } \\
\text { farm }\end{array}$ & Telephone salespersons \\
\hline $\begin{array}{l}\text { Packers \& wrappers, except meat \& } \\
\text { produce }\end{array}$ & Other building \& civil engineering labourers nec \\
\hline Maids \& servants, private household & \\
\hline \multicolumn{2}{|l|}{ Skill group 2} \\
\hline Secretaries, nec & Sales assistants \\
\hline Truck drivers & Clerks (nec) \\
\hline Miscellaneous clerical workers & $\begin{array}{l}\text { Accounts \& wages clerks, book-keepers, other financial } \\
\text { clerks }\end{array}$ \\
\hline Foremen, nec & Drivers of road goods vehicles \\
\hline Sales clerks, retail trade & $\begin{array}{l}\text { Other secretaries, personal assistants, typists, word proces- } \\
\text { sor operators nec }\end{array}$ \\
\hline Cashiers & Metal working production \& maintenance fitters \\
\hline $\begin{array}{l}\text { Machine operatives, miscellaneous } \\
\text { specified }\end{array}$ & $\begin{array}{l}\text { Filing, computer \& other records clerks (inc. legal con- } \\
\text { veyancing) }\end{array}$ \\
\hline Cooks, except private household & Storekeepers \& warehousemen/women \\
\hline Assemblers & Care assistants \& attendants \\
\hline Automobile mechanics & Counter clerks \& cashiers \\
\hline Estimators \& investigators, nec & Electricians, electrical maintenance fitters \\
\hline $\begin{array}{l}\text { Child care workers, except private } \\
\text { household }\end{array}$ & Chefs, cooks \\
\hline Carpenters & Local government clerical officers \& assistants \\
\hline Waiters & Civil Service administrative officers \& assistants \\
\hline Guards \& watchmen & Other childcare \& related occupations nec \\
\hline $\begin{array}{l}\text { Heavy equipment mechanics, includ- } \\
\text { ing diesel }\end{array}$ & Police officers (sergeant \& below) \\
\hline Receptionists & Counterhands, catering assistants \\
\hline Fork lift \& tow motor operatives & Postal workers, mail sorters \\
\hline Sewers \& stitchers & $\begin{array}{l}\text { Motor mechanics, auto engineers (inc. road patrol engi- } \\
\text { neers) }\end{array}$ \\
\hline Policemen \& detectives & Educational assistants \\
\hline Hairdressers \& cosmetologists & Retail cash desk \& check-out operators \\
\hline
\end{tabular}


Table A1: Occupations in each ISCO skill group, UK and US (cont'd)

(a) PSID
Computer \& peripheral equipment op-
erators
Food service workers, nec, except pri-
vate household
Checkers, examiners, \& inspectors;
manufacturing
Salesmen, retail trade
Bank tellers
Salesmen of services \& construction
Miscellaneous operatives
Shipping \& receiving clerks
Bus drivers
Stock clerks \& storekeepers
Electricians
Postal clerks
Typists
Welders \& flame-cutters
Machinists
Clerical supervisors, nec
Painters, construction \& maintenance
Counter clerks, except food
Machine operatives, not specified
Mail carriers, post office
Plumbers \& pipe fitters
Excavating, grading, \& road machine
operators
Miscellaneous mechanics \& repairmen
Air conditioning, heating, \& refriger-
ation
Not specified clerical workers

(b) $B H P S$

Other plant \& machine operatives nec

Receptionists

Bar staff

Assistant nurses, nursing auxiliaries

Security guards \& related occupations

Assemblers/lineworkers (electrical/electronic goods)

Carpenters \& joiners

Bus \& coach drivers

Sewing machinists, menders, darners \& embroiderers

Welding trades

Nursery nurses

Other food, drink \& tobacco process operatives nec

Fire service officers (leading fire officer \& below)

Chemical, gas \& petroleum process plant operatives

Plastics process operatives, moulders \& extruders

Plumbers, heating \& ventilating engineers \& related trades

Gardeners, groundsmen/groundswomen

Fork lift \& mechanical truck drivers

Waiters, waitresses

Assemblers/lineworkers (vehicles \& other metal goods)

Hairdressers, barbers

Skill Group 3

Nursing aides, orderlies, \& attendants Registered nurses

Bookkeepers

Sales representatives, wholesale trade

Insurance agents, brokers, \& underwriters

Teacher aides, except school monitors

Practical nurses

Prekindergarten \& kindergarten

teachers

Officials \& administrators; public administration, nec

Electrical \& electronic engineering technicians

School administrators, elementary \& secondary

Clinical laboratory technologists \&

technicians

Therapists

Health aides, except nursing

Health technologists \& technicians, nec

Health administrators

Nurses

Welfare, community \& youth workers

Technical \& wholesale sales representatives

Accounts \& wages clerks, book-keepers, other financial clerks

Underwriters, claims assessors, brokers, investment analysts

Other sales representatives nec

Laboratory technicians

Computer operators, data processing operators, other office machine operators

Civil Service administrative officers \& assistants

Organisation \& methods \& work study officers

Local government officers (administrative \& executive functions)

Matrons, houseparents

Other scientific technicians nec

Engineering technicians

Medical secretaries

Draughtspersons

Occupational hygienists \& safety officers (health \& safety)

Sales representatives, manufacturing

industries

Real estate agents \& brokers

Buyers \& purchasing officers (not retail) 
Table A1: Occupations in each ISCO skill group, UK and US (cont'd)

\begin{tabular}{ll}
\hline (a) PSID & (b) $B H P S$ \\
Secretaries, legal & Legal secretaries \\
& Midwives \\
\hline
\end{tabular}

Skill group 4

Managers \& administrators, nec

Elementary school teachers

Accountants

Secondary school teachers

Restaurant, cafeteria, \& bar managers

Personnel \& labor relations workers

Bank officers \& financial managers

Social workers

Office managers, nec

Computer systems analysts

Lawyers

Sales managers \& department heads,

retail trade

Farmers (owners \& tenants)

Sales managers, except retail trade

Computer specialists, nec

Physicians, medical \& osteopathic

Electrical \& electronic engineers
Other managers \& administrators nec

Secondary education teaching professionals

Primary \& nursery education teaching profession

Managers \& proprietors in service industries nec

Marketing \& sales managers

Other financial institution \& office managers nec

Production, works \& maintenance managers

Computer analyst/programmers

Social workers, probation officers

Computer systems \& data processing managers

Higher \& further education teaching professionals

Vocational \& industrial trainers

Managers in building \& contracting

Design \& development engineers

University \& polytechnic teaching professionals

Chartered \& certified accountants

Treasurers \& company financial managers

Planning \& quality control engineers

Bank, Building Society \& Post Office managers (except selfemployed)

Personnel, training \& industrial relations managers

Authors, writers, journalists

Restaurant \& catering managers

Solicitors

Medical practitioners

Special education teaching professionals

Transport managers

Clergy 


\section{Appendix B Multinomial Logit estimates}

The Probit estimates in Equations (2), (3) and (4) treat promotion, demotion and exit as three independent binary processes in order to simplify interpretation. It might seem more realistic to model movement as a single multinomial response with outcomes $j=0, \ldots, 3$ where

$$
\begin{array}{ll}
j=0 & \text { Remain in same skill group } \\
j=1 & \text { Move to higher skill group } \\
j=2 & \text { Move to lower skill group } \\
j=3 & \text { Exit employment }
\end{array}
$$

In tables B1 and B2 we report coefficient estimates and marginal effects from the resulting Multinomial Logit models for both the PSID and the BHPS samples.

The marginal effects and significance levels for the probability of promotion and demotion are largely unaffected by the use of a Multinomial Logit rather than a series of Probit estimates. The only exception is in the estimates of the probability of exiting employment (third panel in Tables B1 and B2). Here we find some evidence that skill upgrading does cause an increased probability of exiting employment, particularly for the bottom skill group in the PSID. However, the size of the marginal effects are far smaller than those on the probability of promotion, and so our conclusion still holds.

The difference in the results arises because the Probit and the Multinomial Logit models use a different base group. The Probit estimates of the probability of exit from employment merge $j=0,1,2$ together. 
Table B1: Multinomial Logit estimates of occupational mobility, PSID

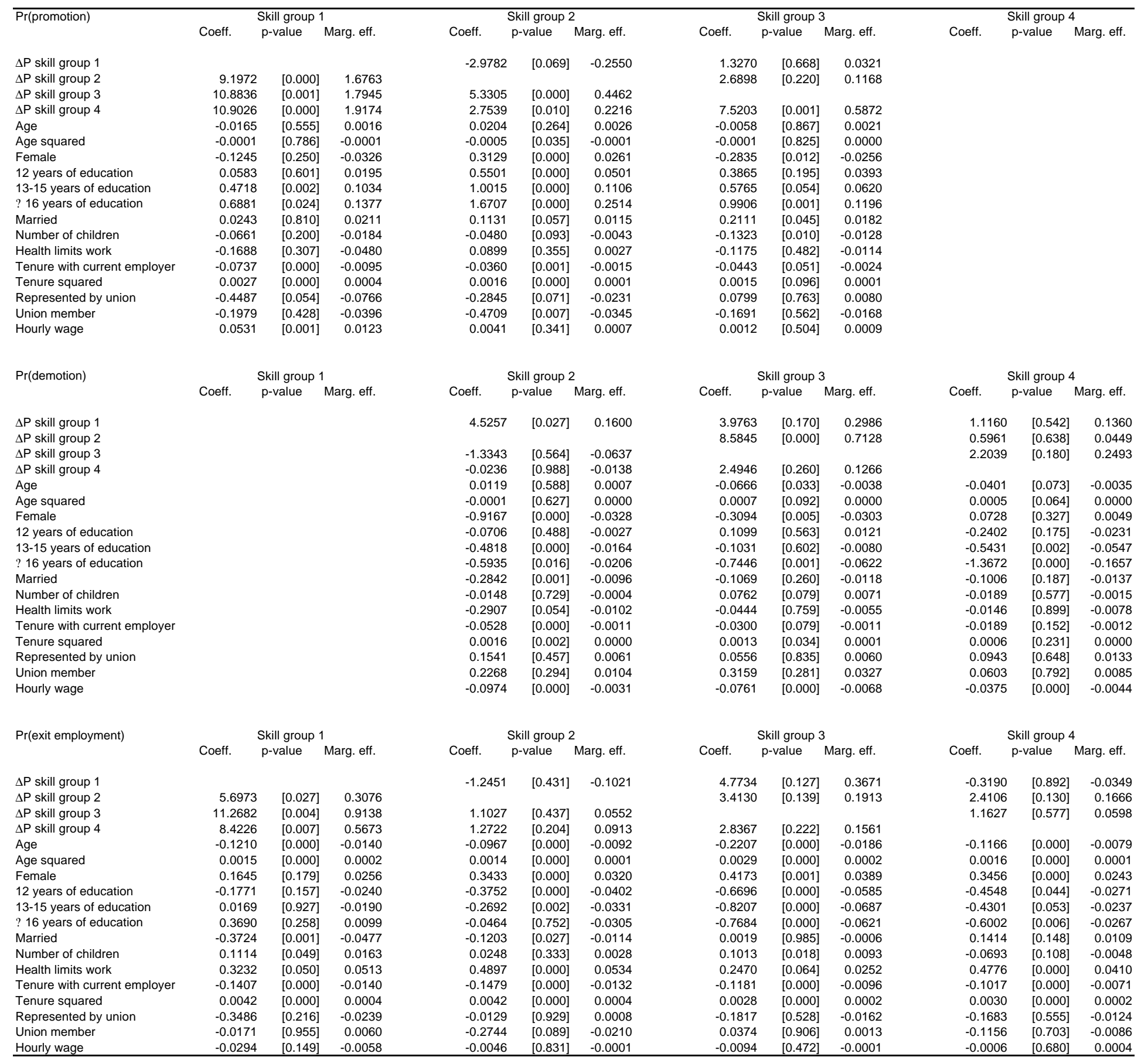


Table B2: Multinomial Logit estimates of occupational mobility, BHPS

\begin{tabular}{|c|c|c|c|c|c|c|c|c|c|c|c|c|}
\hline \multirow[t]{2}{*}{$\overline{\operatorname{Pr}(\text { promotion) }}$} & \multicolumn{3}{|c|}{ Skill group 1} & \multicolumn{3}{|c|}{ Skill group 2} & \multicolumn{3}{|c|}{ Skill group 3} & \multicolumn{3}{|c|}{ Skill group 4} \\
\hline & Coeff. & -value & Marg. eff. & Coeff. & $p$-value & Marg. eff. & Coeff. & $\mathrm{p}$-value & Marg. eff. & Coeff. & $\mathrm{p}$-value & Marg. eff. \\
\hline$\Delta \mathrm{P}$ skill group 1 & \multirow[b]{2}{*}{3.8331} & & & 0.0843 & [0.957] & -0.0022 & 3.7842 & [0.301] & 0.3310 & & & \\
\hline$\Delta \mathrm{P}$ skill group 2 & & [0.038] & 0.6381 & & & & \multirow{2}{*}{2.0476} & {$[0.251]$} & 0.1152 & & & \\
\hline$\Delta \mathrm{P}$ skill group 3 & 2.0998 & [0.441] & 0.2900 & 3.1109 & {$[0.017]$} & 0.2063 & & & & & & \\
\hline$\Delta \mathrm{P}$ skill group 4 & \multirow{2}{*}{$\begin{array}{l}2.6642 \\
0.0157\end{array}$} & {$[0.218]$} & 0.4095 & 1.7207 & {$[0.071]$} & 0.1102 & 6.2478 & {$[0.001]$} & 0.5876 & & & \\
\hline Age & & {$[0.675]$} & 0.0074 & -0.0310 & {$[0.230]$} & -0.0005 & 0.0832 & {$[0.076]$} & 0.0102 & & & \\
\hline Age squared & -0.0006 & [0.165] & -0.0002 & 0.0003 & [0.348] & 0.0000 & -0.0012 & [0.044] & -0.0001 & & & \\
\hline Female & -0.4149 & [0.008] & -0.0753 & -0.0642 & [0.489] & -0.0076 & -0.3654 & [0.013] & -0.0460 & & & \\
\hline 12 years of education & -0.1990 & [0.282] & -0.0284 & 0.3866 & {$[0.002]$} & 0.0300 & -0.0820 & {$[0.767]$} & -0.0076 & & & \\
\hline $13-15$ years of education & 0.2505 & [0.243] & 0.0515 & 0.7432 & {$[0.000]$} & 0.0627 & -0.0142 & [0.958] & 0.0002 & & & \\
\hline ? 16 years of education & -0.0789 & [0.797] & -0.0087 & 1.1240 & {$[0.000]$} & 0.1138 & -0.0158 & [0.953] & 0.0062 & & & \\
\hline Married & -0.1588 & [0.319] & -0.0222 & -0.1107 & {$[0.185]$} & -0.0076 & -0.1523 & [0.293] & -0.0150 & & & \\
\hline Number of children & -0.0061 & [0.937] & -0.0042 & -0.1016 & {$[0.016]$} & -0.0086 & -0.0747 & [0.328] & -0.0103 & & & \\
\hline Health limits work & -0.1970 & [0.394] & -0.0476 & -0.0914 & {$[0.474]$} & -0.0118 & -0.2471 & [0.341] & -0.0324 & & & \\
\hline Tenure with current employer & -0.0202 & [0.390] & -0.0011 & -0.0694 & {$[0.000]$} & -0.0043 & -0.1029 & {$[0.000]$} & -0.0098 & & & \\
\hline Tenure squared & 0.0001 & {$[0.846]$} & 0.0000 & 0.0018 & {$[0.004]$} & 0.0001 & 0.0023 & [0.068] & 0.0002 & & & \\
\hline Represented by union & 0.2291 & [0.244] & 0.0434 & 0.0761 & {$[0.431]$} & 0.0066 & 0.3931 & [0.031] & 0.0357 & & & \\
\hline Union member & -0.1994 & [0.384] & -0.0246 & -0.3239 & {$[0.004]$} & -0.0216 & -0.3507 & {$[0.068]$} & -0.0337 & & & \\
\hline Hourly wage & 0.0386 & {$[0.251]$} & 0.0112 & 0.1111 & {$[0.000]$} & 0.0083 & 0.0255 & {$[0.037]$} & 0.0042 & & & \\
\hline $\operatorname{Pr}$ (demotion) & & kill group & & & Skill group 2 & & & Skill group & & & Skill group 4 & \\
\hline & Coeff. & -value & Marg. eff. & Coeff. & $p$-value & Marg. eff. & Coeff. & $p$-value & Marg. eff. & Coeff. & $p$-value & Marg. eff. \\
\hline$\Delta \mathrm{P}$ skill group 1 & & & & 5.6911 & {$[0.005]$} & 0.0304 & 4.5304 & [0.212] & 0.3212 & 5.1759 & {$[0.008]$} & 0.5066 \\
\hline$\Delta \mathrm{P}$ skill group 2 & & & & & & & 5.2787 & {$[0.004]$} & 0.3826 & 3.8774 & {$[0.000]$} & 0.3684 \\
\hline$\Delta \mathrm{P}$ skill group 3 & & & & 0.4605 & [0.865] & 0.0000 & & & & 2.8329 & {$[0.059]$} & 0.2538 \\
\hline$\Delta \mathrm{P}$ skill group 4 & & & & -0.6398 & {$[0.697]$} & -0.0052 & 3.4420 & {$[0.066]$} & 0.1936 & & & \\
\hline Age & & & & -0.0458 & {$[0.346]$} & -0.0001 & 0.0366 & [0.462] & 0.0035 & -0.0099 & {$[0.774]$} & 0.0003 \\
\hline Age squared & & & & 0.0005 & {$[0.418]$} & 0.0000 & -0.0004 & [0.480] & 0.0000 & 0.0000 & {$[0.917]$} & 0.0000 \\
\hline Female & & & & -0.3449 & {$[0.041]$} & -0.0021 & 0.2508 & {$[0.111]$} & 0.0214 & 0.2475 & [0.013] & 0.0198 \\
\hline 12 years of education & & & & -0.5308 & [0.002] & -0.0028 & -0.2432 & {$[0.337]$} & -0.0193 & -0.1398 & [0.393] & -0.0122 \\
\hline 13-15 years of education & & & & -1.0318 & {$[0.000]$} & -0.0048 & -0.2540 & [0.310] & -0.0206 & -0.3541 & {$[0.031]$} & -0.0322 \\
\hline ? 16 years of education & & & & -0.5003 & [0.033] & -0.0028 & -0.9761 & [0.000] & -0.0781 & -0.7895 & {$[0.000]$} & -0.0779 \\
\hline Married & & & & -0.3589 & {$[0.020]$} & -0.0020 & -0.3779 & [0.011] & -0.0341 & 0.1479 & {$[0.138]$} & 0.0128 \\
\hline Number of children & & & & 0.2021 & {$[0.002]$} & 0.0010 & 0.1967 & {$[0.010]$} & 0.0169 & 0.0149 & {$[0.758]$} & 0.0013 \\
\hline Health limits work & & & & -0.5762 & {$[0.028]$} & -0.0027 & 0.1175 & [0.632] & 0.0052 & 0.0787 & {$[0.675]$} & -0.0001 \\
\hline Tenure with current employer & & & & -0.0479 & [0.068] & -0.0002 & -0.0254 & [0.383] & -0.0004 & -0.0203 & {$[0.277]$} & -0.0019 \\
\hline Tenure squared & & & & 0.0017 & [0.089] & 0.0000 & -0.0001 & [0.913] & -0.0001 & 0.0004 & {$[0.603]$} & 0.0000 \\
\hline Represented by union & & & & 0.5163 & {$[0.003]$} & 0.0030 & 0.4421 & {$[0.019]$} & 0.0318 & 0.1650 & {$[0.177]$} & 0.0181 \\
\hline Union member & & & & -0.1428 & [0.479] & -0.0006 & -0.2339 & [0.241] & -0.0156 & -0.0971 & [0.459] & -0.0091 \\
\hline Hourly wage & & & & -0.1942 & {$[0.000]$} & -0.0011 & -0.1491 & [0.000] & -0.0127 & -0.1064 & {$[0.000]$} & -0.0106 \\
\hline Pr(exit employment) & & ill group 1 & & & Skill group 2 & & & Skill group & & & Skill group 4 & 4 \\
\hline & Coeff. & -value & Marg. eff. & Coeff. & $p$-value & Marg. eff. & Coeff. & $p$-value & Marg. eff. & Coeff. & $\mathrm{p}$-value & Marg. eff. \\
\hline$\Delta \mathrm{P}$ skill group 1 & & & & 0.8827 & [0.532] & 0.0651 & 2.1042 & [0.671] & 0.0745 & 0.4847 & {$[0.854]$} & -0.0073 \\
\hline$\Delta \mathrm{P}$ skill group 2 & 0.6239 & {$[0.770]$} & -0.0359 & & & & 5.2390 & {$[0.030]$} & 0.2821 & 1.9930 & {$[0.219]$} & 0.0884 \\
\hline$\Delta \mathrm{P}$ skill group 3 & 2.5517 & [0.465] & 0.2191 & 2.6064 & {$[0.100]$} & 0.1808 & & & & 3.7103 & [0.094] & 0.1944 \\
\hline$\Delta \mathrm{P}$ skill group 4 & 1.6941 & {$[0.477]$} & 0.1112 & 2.0981 & {$[0.025]$} & 0.1512 & 3.8259 & [0.131] & 0.1702 & & & \\
\hline Age & -0.1765 & {$[0.000]$} & -0.0195 & -0.2570 & [0.000] & -0.0196 & -0.2273 & [0.000] & -0.0153 & -0.1854 & {$[0.000]$} & -0.0106 \\
\hline Age squared & 0.0020 & {$[0.000]$} & 0.0002 & 0.0033 & {$[0.000]$} & 0.0002 & 0.0029 & [0.000] & 0.0002 & 0.0026 & {$[0.000]$} & 0.0001 \\
\hline Female & 0.0873 & {$[0.657]$} & 0.0206 & 0.4838 & {$[0.000]$} & 0.0374 & 0.5078 & {$[0.006]$} & 0.0328 & 0.6626 & {$[0.000]$} & 0.0389 \\
\hline 12 years of education & -0.1952 & [0.385] & -0.0155 & -0.0642 & [0.479] & -0.0073 & 0.1822 & [0.533] & 0.0143 & -0.1872 & {$[0.383]$} & -0.0094 \\
\hline $13-15$ years of education & -0.2286 & [0.428] & -0.0293 & 0.0695 & {$[0.475]$} & -0.0001 & 0.1124 & [0.710] & 0.0090 & -0.0586 & {$[0.769]$} & -0.0011 \\
\hline ? 16 years of education & -0.1836 & [0.530] & -0.0168 & 0.2682 & {$[0.027]$} & 0.0099 & 0.2674 & [0.367] & 0.0233 & -0.1262 & [0.493] & -0.0018 \\
\hline Married & -0.1885 & [0.282] & -0.0163 & -0.0538 & [0.498] & -0.0033 & 0.4249 & [0.032] & 0.0284 & 0.2357 & {$[0.072]$} & 0.0121 \\
\hline Number of children & 0.1176 & {$[0.177]$} & 0.0129 & 0.1914 & {$[0.000]$} & 0.0154 & 0.0377 & [0.690] & 0.0018 & 0.0302 & {$[0.636]$} & 0.0016 \\
\hline Health limits work & 0.5382 & [0.018] & 0.0751 & 0.7100 & {$[0.000]$} & 0.0715 & 0.8050 & {$[0.001]$} & 0.0706 & 0.8091 & {$[0.000]$} & 0.0635 \\
\hline Tenure with current employer & -0.0858 & {$[0.000]$} & -0.0087 & -0.0946 & {$[0.000]$} & -0.0068 & -0.0874 & {$[0.008]$} & -0.0045 & -0.0091 & {$[0.714]$} & -0.0004 \\
\hline Tenure squared & 0.0023 & {$[0.000]$} & 0.0002 & 0.0032 & {$[0.000]$} & 0.0002 & 0.0034 & {$[0.008]$} & 0.0002 & 0.0007 & {$[0.504]$} & 0.0000 \\
\hline Represented by union & -0.1259 & [0.623] & -0.0195 & -0.1993 & [0.049] & -0.0160 & 0.0769 & [0.757] & -0.0010 & -0.2502 & {$[0.127]$} & -0.0153 \\
\hline Union member & -0.3561 & {$[0.258]$} & -0.0313 & -0.0709 & [0.538] & -0.0034 & 0.0328 & [0.896] & 0.0063 & -0.0451 & {$[0.801]$} & -0.0019 \\
\hline Hourly wage & -0.1724 & {$[0.007]$} & -0.0197 & -0.0278 & {$[0.190]$} & -0.0028 & 0.0080 & {$[0.614]$} & 0.0012 & 0.0158 & {$[0.069]$} & 0.0016 \\
\hline
\end{tabular}

